\title{
Homocysteine as a risk factor for cardiovascular and related disease: nutritional implications
}

\author{
Donald G. Weir ${ }^{1}$ and John M. Scott ${ }^{2}$ \\ 'Department of Clinical Medicine \\ ${ }^{2}$ Department of Biochemistry, Trinity College, Dublin
}

\begin{abstract}
The objectives were firstly to assess the evidence that homocysteine is a significant and independent risk factor for vascular disease with special reference to cardiovascular disease, and secondly to evaluate the evidence that a food staple fortified with folic acid will reduce this problem on a population basis.

The structure of plasma homocysteine (tHcy) is described. Homocysteine, a highly reactive compound, is synthesized from the amino acid, methionine, and is metabolized by two pathways, the catabolic transsulphuration route via cystathionine $\beta$-synthase (EC 4.2.1.22) and the remethylation path using 5-methyltetrahydrofolate polyglutamate, the product of 5,10-methylenetetrahydrofolate reductase (MTHFR; EC 1.1.1.171), via the cobalamin dependent enzyme, methionine synthase (MS; EC 2.1.1.13).

The mechanisms whereby hyper-tHcy is produced include both increased rates of synthesis and decreased metabolism. The latter may occur owing to nutritional deficiency of the vitamin cofactors which are necessary for the normal function of the metabolic enzymes. In particular, folate is required for methylene reductase, pyridoxal phosphate for cystathionine synthase and cobalamin for methionine synthase. When these vitamins are deficient hyper-tHcy is induced and this occurs especially in the elderly. Alternatively, a variant form of methylene reductase has recently been described which occurs in nearly $10 \%$ of the normal population. This variant is associated with hyper-tHcy, especially in situations associated with a low folate nutritional status.

Meta-analysis of both retrospective case-control studies, nested prospective case-control surveys and a secondary trial of mortality in postmyocardial infarct patients have shown that the association of hyper-tHcy with vascular disease is beyond doubt. This has been further supported by direct assessments of the degree of vascular disease in the carotid brachial and aortic arteries in relation to thcy levels. Furthermore, treatment with a cocktail of the vitamin cofactors has produced lowering of thcy levels and regression of the vascular disease in the carotid arteries of affected individuals.

Suggested pathogenic mechanisms in vascular disease induced by hyper-tHcy include vascular endothelial cell dysfunction, smooth muscle proliferation and derangements of normal intravascular regulation mechanisms. A variety of clinical conditions are known to be associated with a high incidence of thromboembolic complications. Some of these are associated with hyper-tHcy.

Low physiological doses of folic acid, as well as pharmocological doses, lower tHcy. However, because of the poor bioavailability of food folate $(50 \%)$ and the
\end{abstract}


considerable chemical instability of the naturally occurring reduced forms of folate, in most people it would require unacceptably high consumption of green vegetables to accomplish the necessary increase in intracellular folate and reduction in tHcy. Accordingly, folic acid, the nonreduced synthetic form of the vitamin, which is $100 \%$ bioavailable and chemically extremely stable, should be added to a food staple such as flour to ensure maximum protection for most of the population.

\section{Introduction}

Homocystinuria was first recognized in 1962 (Carson \& Neill, 1962; Gerritsen et al. 1962). The children they described had multiple congenital abnormalities which included severe thromboembolic disease and mental deficiency. Mudd and colleagues (1964) subsequently identified the cause of the homocystinuria as a lack of cystathionine $\beta$-synthase (C $\beta S$ ) (Fig. 2). McCully (1969) then described a child with an inborn error of cobalamin metabolism which resulted in defective methionine synthase (MS) activity, who also had homocystinuria and died of severe vascular disease. As a consequence, McCully \& Wilson (1975) proposed that elevated levels of homocysteine might be pathogenically associated with atheromatous disease of the vasculature. Wilcken \& Wilcken (1976) observed that homocysteine-cysteine mixed disulphide blood levels after a methionine load were raised in patients who had coronary artery disease. This observation has subsequently been confirmed by innumerable studies from many different countries (Boushey et al. 1995).

There are excellent reviews by Green \& Jacobsen (1995), Rosenblatt (1995), Mudd et al. (1995), D'Angelo \& Selhub (1997), Vasikaran \& von Bockxmeer (1997) and Refsum et al. (1998). This review selects and discusses the principal studies published since 1994 with special reference to the nutritional aspects of these developments and their relation to clinical practice.

\section{Structure and properties of homocysteine}

Homocysteine in human plasma is formed by demethylation of the dietary amino acid, methionine, the average dietary intake of which is $>1.8 \mathrm{~g} / \mathrm{d}$ (Mayer et al. 1996). Homocysteine is present in only trace amounts in the diet and is complexed to various thiols. Dietary homocysteine does not, under normal circumstances, appear to affect the plasma homocysteine level (Green \& Jacobsen, 1995). At the first international meeting on homocysteine it was agreed that total plasma homocysteine concentrations would be denoted by the symbol tHcy. Intracellular homocysteine has a short half-life and is rapidly excreted (Ueland \& Refsum, 1989). Whether in the normal range, or considerably elevated (hyperhomocysteinaemia; hypertHcy) thcy is present as a mixture of the dimer homocystine, where two homocysteines are linked via their sulphurs, and mixed disulphides of homocysteine and other thiols such as cysteine or glutathionine (Green \& Jacobsen, 1995) (Fig. 1). Eighty percent of tHcy is protein bound through disulphide links with plasma proteins, especially albumin; less than $5 \%$ of tHcy is free, reduced and nonprotein bound (Araki \& Sako, 1987). Accordingly, chemical reduction is an essential initial step in the measurement of tHcy (Ueland et al. 1993).

The normal range of thcy in our laboratory is $6.0-12.0 \mu \mathrm{g} / \mathrm{l}$ in women and $8.0-14.0 \mu \mathrm{g} / \mathrm{l}$ in men (Wald et al. 1998) but there is some variation between laboratories. tHcy is tightly controlled by metabolic pathways described below. Homocysteine is either degraded via cystathionine to cysteine and pyruvate, or remethylated to methionine. Remethylation can occur via 


$$
\begin{aligned}
& \text { Homocystine } \\
& \text { (oxidized homocysteine) }
\end{aligned}
$$

Homocysteine thiolactone

Homocysteine-cysteine

Homocysteine<smiles>[NH3+]C(CCSSCCC(=O)[O-])C(=O)[O-]</smiles><smiles></smiles><smiles>CSSSCC(=O)[O-]</smiles><smiles>[NH3+][C@H](CCS)C(=O)[O-]</smiles>

Protein-bound homocysteine<smiles>CC(CCSSCC1CC2CCC1C2)C(=O)[O-]</smiles>

Figure 1 Compounds which comprise total plasma homocysteine (derived from Green \& Jacobsen, 1995).

the vitamin $B_{12}$ dependent enzyme methionine synthase or the enzyme betaine homocysteine methyltransferase (EC 2.1.1.5) (Fig. 2). The latter is restricted to liver and kidney in humans (McKeever et al. 1991) and depends on provision of the cosubstrate betaine, a breakdown product of choline.

Ingestion of a very high so-called loading dose of methionine in normal subjects leads to a temporary rise in tHcy, which returns rapidly to baseline. This has been utilized as a functional assay of the 'transsulphuration pathway' for homocysteine catabolism (Fig. 2) and is called the oral methionine loading test (Green \& Jacobsen, 1995). The basis of this test is that C $\beta S$, which controls entry into the transsulphuration pathway, has a high $\mathrm{K}_{\mathrm{m}}$ for homocysteine and thus becomts active only at high homocysteine concentrations. By contrast, methionine synthase has a low $K_{m}$ and is active all the time. The methionine loading test is thus a test of $C \beta S$ malfunction, such as may occur in heterozygotes of $\mathrm{C} \beta \mathrm{S}$ deficiency (Boers et al. 1985) or vitamin $B_{6}$ deficiency. Keeping subjects being tested on a low protein diet is not necessary (den Heijer et al. 1996). 


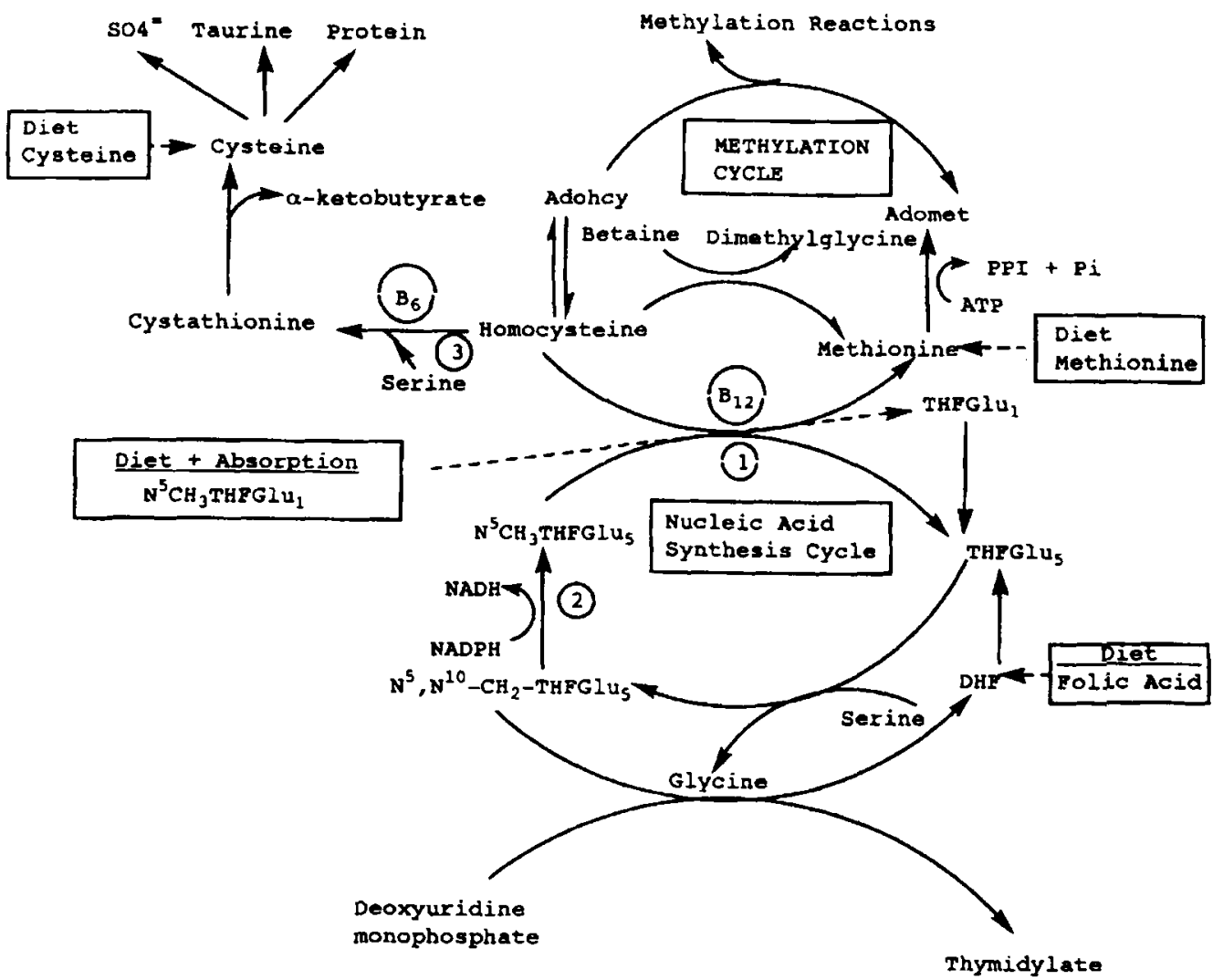

1. Methionine synthase.

2. Methylene tetrahydrofolate reductase.

3. Cystathionine synthase.

Adohcy $=$ adenosyl homocysteine

Adomet $=$ adenosyl methionine

Figure 2 Biochemical pathways associated with homocysteine metabolism.

tHcy levels are higher in men than in women, both fasting and post methionine loading and usually higher in postmenopausal rather than premenopausal women (Boers et al. 1983; Brattström et al. 1984; Kang et al. 1986; Wouters et al. 1995). Postmenopausal women may have levels which exceed those of men of the same age, especially in post methionine loading as compared with fasting tHcy (Wouters et al. 1995). The higher thcy level in men than in women may be due to lower concentrations of B vitamins in men than women (Selhub et al. 1993), but also to the increased muscle mass in men than in women, as $80 \%$ of S-adenosylmethionine (SAM) is used for creatine-creatinine synthesis which inevitably leads to Sadenosylhomocysteine (SAH) and homocysteine (Andersson et al. 1992a) (Fig. 2). 
tHcy also rises with age (Andersson et al. 1992b; Ueland et al. 1993; Selhub et al. 1993; Brattström et al. 1994; Rasmussen et al. 1996; Verhoef et al. 1997), even when allowance is made for age related increase in creatinine and decreasing vitamin levels (Verhoef et al. 1997). The rise may be related to age induced reduction in the function of MS (Dudman et al. 1993) or C $\beta S$ (Nordstrom \& Kjellstrom, 1992). tHcy is also higher in the erect than in the supine position for unknown reasons (C.C. Cronin et al. pers. comm.).

Low concentrations of homocysteine are known to occur in pregnancy (Kang et al. 1986; Andersson et al. 1992b) and in postmenopausal women on hormone replacement drugs (van der Mooren et al. 1994). Homocysteine concentrations are also low in Down's syndrome patients, who have trisomy of chromosome 21 and a low incidence of coronary artery disease (CAD) (Brattström et al. 1987). Since chromosome 21 carries the allele for C $\beta S$ (Skovby, 1985), the extra allele increases the level of the enzyme which enhances the degradation of homocysteine (Chadefaux et al. 1988; Brattström et al. 1989). Low levels have also been recorded in insulindependent diabetics who have not progressed to develop renal and other vascular complications (Robillon et al. 1994).

\section{Biochemical pathways associated with homocysteine}

The concentration of homocysteine in the cell is closely controlled by five enzymes: $S$-adenosylhomocysteine hydrolase (EC 3.3.1.1), which controls its rate of synthesis, and C $\beta S$, MS, methylenetetrahydrofolate reductase (MTHFR) and betaine homocysteine methyl transferase, which control its metabolism.

\section{Synthesis of homocysteine}

Homocysteine is synthesized from dietary methionine, which is an essential amino acid, using the methylation cycle. SAM is first synthesized from methionine using ATP and methionine adenosyltransferase (EC 2.5.1.6). This enzyme is present in three forms, two of which are present in the liver: the $\alpha$ form has a low $K_{m}$ and the $\beta$ form a high $K_{m}$. The $\alpha$ form is present in extrahepatic fetal tissues (Finkelstein, 1990). This enzyme has been cloned (Corrales et al. $1991,1992)$. It has been demonstrated that when oxidation overload occurs glutathione is lowered and methionine adenosyltransferase, which is sensitive to oxidation, is inhibited.

The product of the SAM mediated methylation reactions is SAH. Just as SAM is the universal methylator (Finkelstein, 1990; Weir \& Scott, 1995), so SAH, its product, is its main inhibitor (Weir \& Scott, 1995). The ratio of SAM to SAH (methylation ratio) determines whether the methyl transfer will occur, although different methylation reactions are not equally inhibited by a particular ratio and the degree of inhibition is not linear with the fall in the ratio (Weir \& Scott, 1995). This is relevant to hyper-tHcy, since all causes of raised thcy will automatically produce high levels of SAH (de la Haba \& Cantoni, 1959). Although SAH is normally converted to adenosine and homocysteine by SAH hydrolase, the equilibrium of the reaction favours SAH formation (de la Haba \& Cantoni 1959). Thus, the flow of SAH through the hydrolase to homocysteine requires the continuous removal of either adenosine or homocysteine. Elevation of either will inevitably increase SAH if the other product is also present. Whatever may be the effect of homocysteine on fetal nerve and vascular endothelial cells, prolonged hyper-tHcy could produce toxic effects by elevating intracellular and circulating SAH which would, in turn, switch off one or more of the methyltransferase reactions. 
As explained above, homocysteine is either degraded via the transsulphuration pathway using $\mathrm{C} \beta \mathrm{S}$, or is remethylated back to methionine either by MS which uses the product of MTHFR, 5methyltetrahydrofolate, or by betaine homocysteine methyltransferase (Fig. 2).

\section{Cystathionine $\beta$-synthase (CBS)}

The biochemistry of this enzyme (Fig. 2, no. 3) is described in detail elsewhere (Finkelstein, 1990; Mudd et al. 1995). This is a catabolic reaction, it transsulphurates homocysteine using serine, and in so doing produces cystathionine and subsequently cysteine and $\alpha$-ketobutyrate, both of which are pyridoxal phosphate (PLP) dependent reactions. Cysteine is then used for protein biosynthesis or it can be used by cystathionine $\gamma$-lyase (EC 4.4.1.1) to make glutathione.

The genes encoding $\mathrm{C} \beta \mathrm{S}$ have been cloned and are found on chromosome 2 (Kraus $e t$ al. 1993). The enzyme was isolated from human liver (Kraus, 1994) and was found to be a tetramer with subunits of $63 \mathrm{kDa}$. Post-translation, this becomes a dimer, which has a sixtyfold lower $\mathrm{K}_{\mathrm{m}}$ for homocysteine and is thirty times more active (Skovby et al. 1984). Defects are known to occur in the C $\beta S$ enzyme and the genes coding for it have also been cloned and sequenced (Tsai et al. 1996a). Cumulatively, the heterozygosity for the different genetic variants for the $C \beta S$ defect occurs in only $1 / 200$ of the general population.

\section{5,10-Methylenetetrahydrofolate reductase}

A detailed discussion of the properties of this enzyme has been given by Matthews (1984). It catalyses the reduction of 5,10-methylenetetrahydrofolate using NADPH in a two step process. The first synthesis is to the quinonocol form of 5-methyldihydrofolate, followed by its reduction by FADH to 5-methyltetrahydrofolate (Matthews \& Haywood, 1979). The enzyme is inhibited by SAM (Kutzbach \& Stokstad, 1971). This is important because the enzyme really controls the provision of methyl groups into the methylation cycle. It has been sequenced and cloned and several mutations and one variant have been identified at the genomic level (Goyette et al. 1994).

\section{Methionine synthase}

A detailed discussion of properties of this enzyme has been given by Matthews (1984). The mammalian form requires methyl cobalamin as a cofactor. The enzyme reaction uses the methyl group attached to the cofactor to methylate homocysteine. The cobalamin form that is generated in this reaction is called Cob(I)alamin. It has an unpaired electron and is very unstable. Usually it immediately takes the methyl group from 5-methyltetrahydrofolate to regenerate the original and stable form, methylcobalamin, and this goes on to repeat the cycle. However, about every fifty cycles of the enzyme, $\mathrm{Cob}(\mathrm{I})$ alamin is oxidized by molecular oxygen to Cob(II)alamin. The enzyme with this form of the cofactor cannot accept the methyl group from 5-methyltetrahydrofolate, which effectively inactivates the enzyme. However, Cob(II)alamin can be reactivated by accepting a methyl group not from 5-methyltetrahydrofolate but from SAM. This latter process also requires a reduction of the cobalamin cofactor. The anaesthetic gas nitrous oxide $\left(\mathrm{N}_{2} \mathrm{O}\right)$ inactivates methionine synthase. It seems clear that 
this oxidation does not follow the pattern of oxidation with molecular oxygen. Instead a hydroxy radical is produced which attacks the protein structure of the enzyme causing its irreversible denaturation (Drummond \& Matthews, 1994).

\section{Mechanisms of hyperhomocysteinaemia}

Hyper-tHcy can result either from enhanced production, or from reduced rates of metabolism of tHcy.

\section{Enhanced homocysteine synthesis}

This occurs acutely when a subject eats a protein meal which contains a large quantity of methionine (Fig. 2). This forms the basis of the methionine loading test. Normally the elevated tHcy level is present for only a short period. Prolonged elevation suggests that there is a defect in the transsulphuration pathway via $\mathrm{C} \beta \mathrm{S}$.

\section{Reduced homocysteine metabolism}

A reduced rate of homocysteine metabolism occurs when there is a defect in any of the enzymes or deficiency of their vitamin cofactors. Thus, reduction in activity of C $\beta S$, MTHFR or MS, or availability of their cofactors, pyridoxine, folate and cobalamin respectively, can cause hyper-tHcy (Table 1). Enzymes may malfunction due to inherited mutations or to dietary deficiencies, or perhaps secondary to other acquired metabolic diseases. Defects of betaine homocysteine methylene transferase have not been described.

\section{Inherited mutations}

The mechanisms of these defects are discussed in detail by Boers et al. (1985), Fenton \& Rosenberg (1989), Green \& Jacobsen (1995), Rosenblatt (1995) and Tsai et al. (1996a,b). Inherited defects result from less than a dozen mutations of the gene for MTHFR. Such

Table 1b. Causes of Hyperhomocysteinaemia

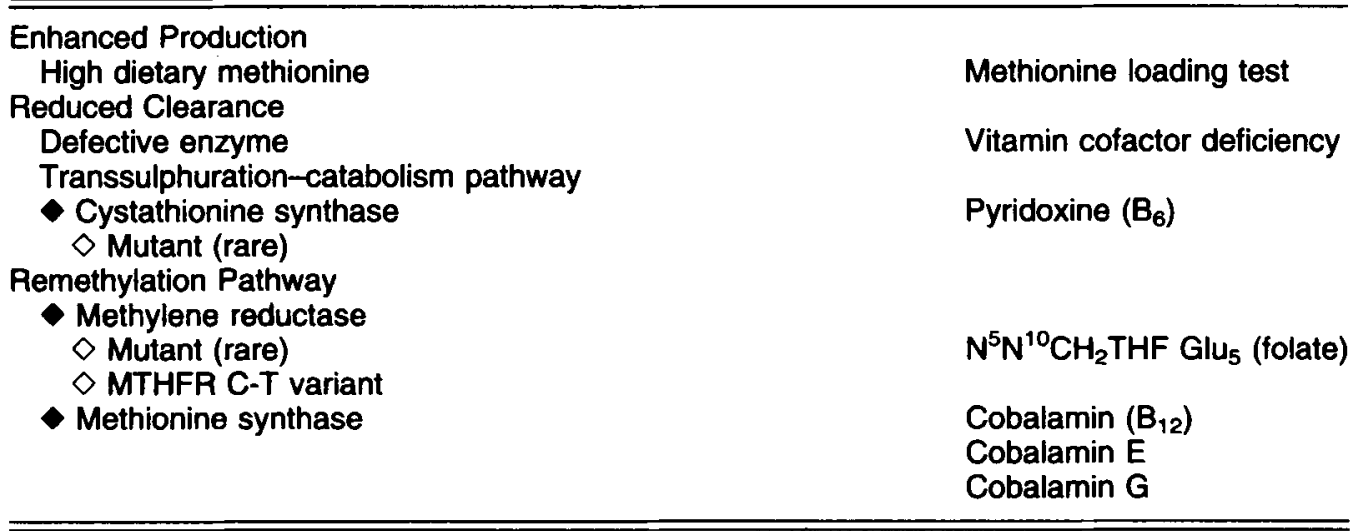


mutations are extremely rare, patients who are homozygous for such mutations numbering less than one hundred. More recently an unstable thermolabile variant form of MTHFR has been described (Kang et al. 1988a). Subsequently the relevant abnormality in the MTHFR gene where a cytosine to thymine switch in the 677 base resulted in transcriptions of alanine instead of valine has been recognized (Frosst et al. 1995). Nearly half of most populations studied are heterozygous, and 5-20\% homozygous (van der Put et al. 1997). The very high prevalence of this genetic abnormality means that it is called a variant rather than the classically recognized mutants of low frequency.

\section{Nutritional deficiencies}

Deficiency of one or other of the three vitamins (folate, $B_{6}$ and $B_{12}$; Table 1 ) is common, especially among the elderly (Joosten et al. 1993; Selhub et al. 1993; Naurath et al. 1995). This is especially true of folate, although cobalamin and to a lesser extent PLP deficiency also occur in the elderly. Selhub and colleagues (1993) studied 1160 survivors of the Framingham Heart Study cohort, 67-96 years old. They showed that tHcy increased with age after controlling for vitamin concentrations. There was a strong inverse relationship between tHcy and plasma folate after controlling for age, sex and the levels of the other vitamins. Weaker inverse associations were also found with plasma cobalamin and PLP. There was an association between tHcy and the dietary intake of folate and PLP, but not of $B_{12}$. The authors concluded that inadequate plasma concentrations of one or more B vitamins contributed to $67 \%$ of the cases of high tHcy. tHcy levels were elevated in patients with dietary folate intakes up to $280 \mu \mathrm{g} / \mathrm{d}$, which is in excess of the current recommended dietary allowance or reference nutrient intake of $200 \mu \mathrm{g} / \mathrm{d}$ (Department of Health, 1991). In a carefully controlled study of normal male volunteers in a metabolic ward, Jacob and coworkers (1994) demonstrated that thcy increases as plasma folate decreases and that restriction of dietary methyl groups (methionine) did not increase dietary folate requirements.

thcy and methylmalonic acid concentrations rise when plasma levels of folate and cobalamin are in excess of what are conventionally considered to be the lower limits of normal (Kang et al. 1988b; Stabler et al. 1990; Allen et al. 1993; Joosten et al. 1993; Selhub et al. 1993; Naurath et al. 1995). tHcy and methylmalonyl CoA are the substrates for the two mammalian cobalamin-dependent enzymes, MS and methylmalonyl CoA mutase (EC 5.4.99.2). Along with $\mathrm{N}^{5} \mathrm{CH}_{3}$-THF-Glus, $\mathrm{tHcy}$ is the substrate for MS (Fig. 2). Dysfunction of the mutase enzyme results in elevation of methylmalonyl CoA which degrades to methylmalonic acid and is excreted in the urine. Thus, a rise in these substrates gives a clear indication of one or other vitamin deficiency. Methylmalonic acid and tHcy will be elevated in $B_{12}$ deficiency, while only thcy is raised in folate deficiency.

What is an adequate intracellular concentration of a vitamin such as folate has been questioned by Daly and coworkers (1995). They re-analysed data derived from an earlier study of 50000 women who attended antenatal clinics in the Dublin maternity hospitals in the late 1980s (Kirke et al. 1993). Of these women, 81 subsequently delivered a child with neural tube defect (NTD). When the maternal red cell folate (RCF) levels were assessed it was apparent that the risk of delivering an NTD baby was present throughout the range of RCF values, but the prevalence progressively increased the lower the RCF level. The accepted cutoff level of normal RCF at present is $150 \mu \mathrm{g} / \mathrm{ml}$ or above. This level, because of the shape of the curve, results in a prevalence of 5-6 NTD births per thousand live births (Daly et al. 1995). The prevalence drops rapidly as the RCF increases with progressively less reduction of risk as the 
level exceeds $400 \mathrm{~g} / \mathrm{l}$. This level at which the risk of an NTD is reduced tenfold from the levels seen at $150 \mathrm{~g} / \mathrm{l}$, has been used as a compromise target for dietary folate therapy, i.e. to reduce NTD as far as possible without exposing the population to the potential risks of too high levels of folic acid (Daly et al. 1997; Kelly et al. 1997).

The question of how to ensure that all women attain an RCF level in excess of $400 \mu \mathrm{g} / \mathrm{ml}$ is thus very relevant. Recent evidence suggests that for the population to attain such a level and lower tHcy maximally would be difficult by dietary folate alone, because dietary folate is only $50 \%$ bioavailable (Gregory, 1995). The only effective way is to take folic acid which is $100 \%$ bioavailable, either as tablets or as food staples such as flour or breakfast cereals fortified with folic acid (Cuskelly et al. 1996). Folic acid is extremely stable chemically, unlike the natural folate where the pteridine ring is reduced to the tetrahydro form, making oxidative cleavage of pteridine to the $p$-aminobenzoic acid-glutamic acid residue very possible (Blakley, 1969). Since the fetal neural tube closes 24-28 d after conception, well before the mother is aware that she is pregnant, it is important to ensure that she is taking the folic acid supplement periconceptually (i.e. during any period when she might become pregnant). Numerous studies have shown that young women, even if they are aware of the risk, are poor compliers at taking folic acid tablets daily (Wild et al. 1996a,b). This is because in most societies over half of all pregnancies are unplanned. The only effective way to ensure that the majority of the population are benefiting maximally is to fortify a food staple such as flour (Oakley, 1997a). Following the recommendations of the Food and Drug Administration and the Folic Acid Working Party Group of the Centres for Disease Control and Prevention, it is now a law in the USA that flour will be fortified with $140 \mu \mathrm{g}$ folic acid $/ 100 \mathrm{~g}$ cereal grain product which, it is calculated, will ensure that most Americans will receive at least $100 \mu \mathrm{g}$ folic acid/d (Tucker et al. 1996; Oakley, 1997a).

Is $100 \mu \mathrm{g}$ folic acid/d enough to achieve the necessary red cell folate levels and lower thcy to the maximum extent? It is well known that pharmacological doses of folic acid will achieve levels of RCF $>400 \mu \mathrm{g} / 1$ (Brattström et al. 1988, 1990; Malinow et al. 1990; Landgren et al. 1995 ) but only at the expense of the unphysiological form of folate, folic acid, appearing in the blood (Kelly et al. 1997).

Methyl folate $\left(\mathrm{N}^{5} \mathrm{CH}_{3} \mathrm{THF}\right.$ Glu $)$, the normal circulating form of folate in the blood, enters cells by a process controlled by cobalamin dependent MS (Fig. 2). In $\mathrm{B}_{12}$ deficient patients methyl folate cannot enter the cell whereas folic acid enters by a noncobalamin dependent process (Fig. 2). Folic acid can thus maintain the supply of intracellular folate required for the synthesis of thymidylate and DNA. Accordingly, folic acid will treat the megaloblastic anaemia that occurs in cobalamin deficiency, but will not affect the neurological complications which require the synthesis of SAM (Scott et al. 1981). Thus, folic acid might by treating the anaemia allow the irreversible neurological disease to progress undiagnosed, which would not occur if the anaemia were correctly treated with $\mathrm{B}_{12}$ (Scott \& Weir, 1981).

Recent evidence suggests that small physiological doses of folic acid, which are converted by the intestine to methyl folate and are therefore not likely to mask the neuropathy (Kelly et al. 1997), will also reduce tHcy (Ward et al. 1997) and elevate RCF (Daly et al. 1997; Malinow et al. 1998). Ward and coworkers (1997) gave 30 normal adult volunteers with thcy levels within the normal range varying levels of folic acid: $100 \mu \mathrm{g} / \mathrm{d}$ for six weeks, followed by $200 \mu \mathrm{g} / \mathrm{d}$ for six weeks, followed by $400 \mu \mathrm{g} / \mathrm{d}$ for six weeks and finally six weeks with no added folic acid. The group was divided into tertiles depending on their initial tHcy. After $100 \mu \mathrm{g}$ folic acid/d there was a significant fall in the thcy levels in the upper and middle tHcy tertiles, but no significant effect in the lowest tertile. After $200 \mu \mathrm{g}$ folic acid/d there was a further significant fall in the upper and middle tertiles, but none in the lowest. After $400 \mu \mathrm{g} / \mathrm{d}$ there was no further 
significant fall, and following a further six weeks without folic acid, in the upper and middle tertiles there was a significant rise to former levels once again. These results show that a significant effect was obtained with $100 \mu \mathrm{g} / \mathrm{d}$ and a maximal effect with $200 \mu \mathrm{g} / \mathrm{d}$ over periods of six weeks. The authors argued that $100 \mu \mathrm{g}$ folic acid/d taken for a lifetime in a food staple such as flour would be likely to have as complete an effect as $200 \mu \mathrm{g}$ folic acid/d over six weeks did in this study (Ward et al. 1997).

In a study conducted on 747 elderly subjects 67 to 96 years old who were members of the Framingham Heart Study group (Tucker et al. 1996) it was demonstrated that folic acid fortification of flour significantly increased both the folate content of the diet and the RCF levels and lowered the thcy values. They argued that at a level of fortification of $140 \mu \mathrm{g} / 100 \mathrm{~g}$ cereal grain product the ensuing benefits would greatly outweigh the harm induced by the potential masking of the onset of the neurological complications of vitamin $\mathbf{B}_{12}$ deficiency. They suggested that much of this problem could be alleviated by adding $B_{12}$ as well as folate to the staple diet. Recently the results of a randomized double-blind controlled trial have been published (Daly et al. 1997). Participants were randomly allocated to receive 0,100 or $400 \mu \mathrm{g}$ of folic acid daily for a period of six months and compliance was strictly monitored. Whereas $400 \mu \mathrm{g}$ folic acid caused a doubling of the RCF, a significant increase was also obtained with both 100 and $200 \mu \mathrm{g}$ doses. This study suggests that the US policy of fortifying flour with sufficient folic acid to ensure an increase of $100 \mu \mathrm{g}$ folic acid/d is appropriate, since this dose attained the $400 \mu \mathrm{g} / \mathrm{ml}$ RCF level which was suggested by Daly et al. (1995) as sufficient to produce maximal practical protection from NTD. This is likely to have a dramatic effect on the incidence of both NTD and vascular related deaths in the USA over the next decade.

PLP deficiency is also associated with raised tHcy (Robinson et al. 1995, 1997; Morrison et al. 1996) and may be the reason for the high percentage of cardiac patients with abnormal post-methionine load tests found in the European COMAC Group (Robinson et al. 1997). Once again, the risk of vascular disease decreased with rising PLP values. Although PLP deficiency did not appear to influence the thcy level in the same way as folate deficiency, it was nevertheless an independent risk factor for arteriosclerotic vascular disease.

\section{Evidence for a pathogenic association between mild hyperhomocysteinaemia and vascular disease}

It is known that in patients with homocystinuria and thcy levels $>100 \mu \mathrm{g} / \mathrm{ml}$, reduction of the tHcy level will reduce the incidence of vascular events (Mudd et al. 1995). However, in order to prove that the reduction of mild hyper-tHcy (i.e. tHcy $<100 \mu \mathrm{g} / \mathrm{ml}$ ) will prevent the development of atherosclerotic vascular disease would require a primary prevention study showing that when tHcy levels are lowered there is a reduction in the mortality and morbidity from vascular events such as coronary thrombosis or strokes, when compared with suitable controls. Such a study has never been conducted as the numbers of subjects and time required to establish such a cause and effect, combined with ethical considerations, would be prohibitive.

Nevertheless, secondary prevention trials are under way which could prove that lowering tHcy in subjects who have already had a vascular event will prevent a recurrence (Vasikaran \& van Bockxmeer, 1997). The biggest trial of all will be the effect in the USA on the prevalence of vascular events following the introduction in 1998 of compulsory fortification of flour with $140 \mu \mathrm{g}$ folic acid/100 $\mathrm{g}$ (Oakley, 1997a). This, it has been estimated, will save in the region of 50000 lives per annum (Boushey et al. 1995). Only time will tell. 


\section{Retrospective and prospective case-control studies}

In the meantime, evidence has accumulated from both retrospective and prospective (nested case-control) studies that a raised tHcy is associated with atheromatous and thrombotic vascular events. It is known that mild homocysteinaemia is associated with coronary artery disease (Boushey et al. 1995) and cerebral (Brattström et al. 1992; Perry et al. 1995) and peripheral occlusive arterial disease (Brattström et al. 1990; Aronson et al. 1994) in relatively young patients (under 60 years). Hyper-tHcy is also associated with thromboembolic disease of the venous system. The evidence is fully reviewed by D'Angelo \& Selhub (1997). The syndrome is characterized by recurrent episodes of thrombosis at a relatively young age, after minimal provocation and in unusual sites. Ten studies have so far been reported, of which eight have found a significantly positive association (see D'Angelo \& Selhub, 1997 for references). HypertHcy is also an independent risk factor for hyperlipaemic patients (Glueck et al. 1995). These studies and others (Pancharuniti et al. 1994; Morrison et al. 1996) show that there is usually a correlation between tHcy and the plasma concentrations of cobalamin, PLP and folate. The level of tHcy always responds to treatment with these vitamins albeit when given in pharmacological doses. The risk of cardiovascular disease mortality was also correlated with the mean tHcy level in randomly chosen men in 11 different countries (Alfthan et al. 1997).

\section{Retrospective case-control studies}

A quantitative meta-analysis was conducted by Boushey and colleagues (1995) using mostly retrospective case-control studies. They evaluated 27 studies relating thcy to arterial vascular disease and eleven studies of the effect of folic acid therapy on tHcy.

\section{Effect on coronary artery disease}

In 14 of 17 studies into CAD thcy was a significant risk factor. A $5 \mu \mathrm{mol} / 1$ rise in thcy was associated with CAD in men (odds ratio (OR) 1.6; $95 \%$ confidence interval (CI) 1.4-1.7) and in women $(1.8 ; 1.3-1.9)$. They calculated that $10 \%$ of all CAD risk in the population was due to tHcy. The vascular response to tHcy was graded throughout the range of homocysteine values, showing no threshold association. This is similar to the association between serum cholesterol and vascular disease.

\section{Effect on cerebrovascular events}

Cerebrovascular disease (CVD) also showed a positive association with thcy in nine of eleven studies $(2.5 ; 2.0-3.0)$. A significant fall in the incidence of CVD is likely with a fall of $5 \mu \mathrm{mol} / 1$ in fasting tHcy $(2.3 ; 1 \cdot 8-2.0)$. If only the three best studies are analysed, the effect of tHcy is still significant (1.5; 1.3-1.9) (Boushey et al. 1995). These effects were apparent even taking into account the temporary lowering of tHcy in the acute phase following a stroke.

\section{Peripheral vascular disease}

All nine studies which examined the effect of thcy on this form of vascular disease gave a positive association $(6.8 ; 2.9-15.8)$ (Boushey et al. 1995).

\section{Other retrospective case-control studies}

A major study reported from the European Concerted Action Project by Graham and colleagues (1997) assessed 750 patients with cardiac, cerebral and peripheral vascular disease from 19 
separate European centres. These subjects were below the age of 60 years, included both sexes and were matched by 800 appropriate controls. The results showed that there was a significantly higher incidence of vascular disease in the upper $20 \%$ as opposed to the lower $80 \%(2.2 ; 1.6-$ 2.9). The results of the methionine loading test, when added to those of the fasting tHcy, added a further $27 \%$ of cases to those deemed to be at risk. A dose response was noted between the tHcy level and the risk of vascular disease, which was independent of the other risk factors such as smoking and high blood pressure and was of similar magnitude. The relative risk per $5 \mu \mathrm{mol} / \mathrm{l}$ thcy increment was remarkably similar and as significant as that calculated in the meta-analysis of Boushey et al. (1995).

In both sexes there was a multiplicative effect of high tHcy, smoking and high blood pressure. No such effect was found for plasma cholesterol concentration. As in other studies, RCF, plasma cobalamin and PLP concentrations were inversely related to thcy. People who took vitamin tablets were at a substantially lower risk of vascular disease and this was associated with lower tHcy.

The authors concluded that hyper-tHcy increases the risk of vascular disease to the same extent as smoking and hyperlipidaemia and that both smoking and high blood pressure markedly enhance the risk of hyper-tHcy.

\section{Prospective (or nested case-control) studies in vascular disease \\ Primary prospective studies in ischaemic heart disease (IHD).}

Although, as described above, retrospective case-control studies show a clear relationship with IHD (Boushey et al. 1995), primary prospective cohort studies have been less conclusive. Of the four studies conducted to date, two have shown a negative relationship with tHcy (Stampfer et al. 1992; Alfthan et al. 1994) and two have been positive (Arnesen et al. 1995; Wald et al. 1998).

The US Physicians' Health Study (Stampfer et al. 1992) reported on the development of 271 IHD events, both fatal and nonfatal in their cohort of 14916 US male physicians. These were matched by 271 controls; average age at the time of the IHD event was 62 . Initially there was an association between IHD and tHcy in the upper $5 \%$ of the tHcy distribution, compared with the lower $90 \%(3.1 ; 1.4-6.9)$. However, after a longer follow-up period, this difference fell to 1.3 which was no longer significant (Verhoef \& Stampfer, 1995). A further report (Chasan-Taber et al. 1996) showed that both folate and pyridoxine deficiency were commoner, although not significantly so, in those who subsequently went on to develop a myocardial infarct. This was present even when controlled for diabetes, angina, hypertension, body mass index and lipoprotein cholesterol. Adding the effect of thcy to this model did not add to the significance of the prediction values, except as described above in the early period of the study. The authors still concluded that these data are compatible with the hypothesis that low dietary intakes of folate and/or vitamin $\mathrm{B}_{6}$ contribute to the risk of $\mathrm{Ml}$. One interesting factor in this study was that hypertension was found to correlate positively with $\mathrm{tHcy}(\mathrm{P} \leq \mathbf{0 . 0 0 3})$ and is similar in this respect to the study by Graham and colleagues (1997).

Alfthan and colleagues (1994) in Finland studied 191 patients with IHD, both fatal and non-fatal and compared them with 269 controls. Males and females were included and their average age was 61 years. The OR was $1.00(0.77-1.29)$.

In contrast, a study by Arnesen and colleagues (1995) demonstrated a significantly positive association between cardiovascular disease and thcy. In this nested case-control study in Tromso, of 21626 subjects 12-61 years old, 123 developed IHD within a mean follow-up period of four years. Ninety percent of these cases were males and for each case identified, four 
controls were selected and matched for age, sex and number of hours since last meal when venesection occurred. The level of thcy in cases and controls was $12.7 \pm 4.7 v$. $11.3 \pm 3.7 \mu \mathrm{mol} / \mathrm{l}$ (mean \pm S.D.; $\mathrm{P}<0.002$ ). The relative risk of a $4 \mu \mathrm{mol} / 1$ rise in thcy was $1.41(1.16-1.71)$. When adjustment was made for potential factors, the OR was $1.32(1.05-$ 1.65). There was no threshold level of thcy at which the risk of IHD emerged. Thus, tHcy was an independent risk factor for IHD, the association was not as high as for total and very low density lipoprotein cholesterol and smoking, but was higher than for diabetes mellitus and systolic blood pressure.

A nested case-control study from London and Dublin on blood samples collected from members of the British United Provident Association (BUPA) reported on 21520 men 35-64 years old who had no evidence of IHD at baseline (Wald et al. 1998). Subsequently, 229 men died of IHD during a mean follow-up of 8.7 years. Five age matched controls with no evidence of IHD were selected for each case, giving a total of 1126 . tHcy was higher in cases than controls (mean 13.1 v. $11.8 \mu \mathrm{mol} / \mathrm{l}, \mathrm{P}<0.001$ ). The risk of IHD in the highest quartile of thcy was 3.7 times that in the lowest quartile (95\% CI 1.8-4.7), or 2.9 times after adjusting for other risk factors. For each $5 \mu \mathrm{mol} / 1$ rise in tHcy there was a continuous dose response relationship which increased risk by $41 \%$ (95\% CI 22-59).

In a meta-analysis of the eight previous restrospective studies of the relationship between thcy and IHD, carried out by Wald et al. (1998), the age adjusted association was stronger. For each $5 \mu \mathrm{mol} / 1$ increase in tHcy, the rate of IHD risk increase was $84 \%$ (95\% CI 52-123). The reason why the retrospective, as compared with the prospective, analyses show a stronger association is not immediately apparent, but may relate to the mean age of subjects in the prospective trials being ten years older than in the retrospective studies. The association is strongest when IHD occurs in young subjects (Verhoef \& Stampfer, 1995; Wald et al. 1998). A similar phenomenon has been reported for other IHD risk factors, such as cholesterol (Law et al. 1994), blood pressure (Neaton \& Wentworth, 1992) and smoking (Kahn, 1966). Alternatively, there are clear methodological differences between the prospective and retrospective studies. In the former, there is no possibility of the cases being different in any significant way from the controls with respect to collection and analysis. However, in the latter questions arise such as: was the elevation of homocysteine in the cases a result, rather than a cause? Were the controls truly matched to the cases? Were the samples treated identically? (e.g. blood on standing releases significant homocysteine). Were collection methods identical in cases and controls?

\section{Prospective study in cerebrovascular disease.}

A study by Perry and colleagues (1995), from the British Regional Heart Study Group, who had obtained serum samples from 5661 men 40-59 years old from 18 towns in the UK, looked prospectively at the relationship of thcy to the development of a stroke. During a follow up period of a mean 12.8 years, 141 incidences of stroke occurred in men who had no history of stroke at screening. tHcy was obtained in 107 cases and 118 matched controls. tHcy was significantly higher in cases than controls $(13.7 ; 12.7-14.8 v .11 .9 ; 11.3-12.6 \mu \mathrm{mol} / 1 ; \mathrm{P}=0.004)$.

Once again the relative risk of stroke was graded throughout the quartiles of tHcy. The relative risk of second, third and fourth quartiles with respect to the first gives an OR respectively of $1.3,1.9$ and $2.8(\mathrm{P}=0.005)$. No association was found with body mass index, hypertension, smoking, alcohol intake, diabetes, high density lipoprotein cholesterol or creatinine. The authors concluded that thcy is a strong and independent risk factor for stroke.

A similar study by Verhoef and colleagues (1994) in 109 cases and 427 controls, from an initial total of 14916 subjects followed for 5 years, showed a mild but insignificant association 
with tHcy (cases $v$. controls $11 \cdot 1 \pm 4.0 \mathrm{SD} v .10 .6 \pm 3.4, \mathrm{P}=0.12$ ). However, the duration of the trial was less than that of Perry et al. (1995).

\section{Direct association of vascular damage and homocysteine}

The relationship of the level of thcy to the degree of arteriosclerotic thickening of the carotid wall was assessed by an ultrasound method by Malinow and colleagues (1993). Pairs of asymptomatic adults (287) were selected from a probability sample of 15800 men and women 45-65 years old. Subjects with thickened intimal-medial carotid walls had higher tHcy levels than controls $(P<0.001)$. The relative risk of having a thickened carotid artery wall for those with tHcy $>10.5 \mu \mathrm{mol} / \mathrm{l}$ as compared with those $<5.88 \mu \mathrm{mol} / 1$ was $3.15(1.57-6.33)$.

A similar study was conducted by Selhub and colleagues (1995) on 1041 elderly subjects 67-96 years old who were members of the Framingham Heart Study Cohort. Using ultrasonography, they found that $43 \%$ of men and $34 \%$ of women had $>25 \%$ carotid artery stenosis. The incidence of $>25 \%$ occlusion of the carotid artery was higher when thcy was $>14.4 \mu \mathrm{mol} / \mathrm{l}$, than when $<9.1 \mu \mathrm{mol} / \mathrm{l}$. The OR was $2.0(1.4-2.9)$ after adjusting for sex, age, high density lipoprotein cholesterol, systolic blood pressure and smoking. Plasma folate, pyridoxine and dietary folate intake were inversely associated with the degree of carotid artery stenosis after adjusting for the risk factors.

More recently, Konecky and colleagues (1997) used transoesophageal echocardiography to evaluate 156 patients with atheromatous plaques in their thoracic aorta. tHcy was significantly associated with aortic disease $(P<0.001)$ and was independently predictive when other risk factors were excluded. Interestingly, only plasma vitamin $B_{6}$ correlated with the degree of atheromatous change.

Following an acute rise in thcy induced by a methionine loading test in normal volunteers, a significant reduction in the mean brachial artery dilatation associated with the rate of blood flow was found, suggesting an acute and direct effect of homocysteine on endothelial function (Chambers et al. 1998). Brachial artery flow is endothelium dependent and dilatation is largely mediated by NO. These findings suggest that hyper-tHcy impairs the response to endothelial NO in healthy subjects.

Finally, in 38 patients in whom carotid artery atheromatous plaque size had been demonstrated to be enlarging prospectively and whose thcy was $>14 \mu \mathrm{mol} / \mathrm{l}$, it has been shown that treatment with folic acid, pyridoxine and $B_{12}$ over a mean period of 4.4 years produced a significant regression of the plaque size (Petersen \& Spena, 1998).

These studies give direct support for a positive relationship between tHcy and vascular disease as measured in the carotid arteries and the aorta in asymptomatic living subjects. In all studies, the pathogenic effect of homocysteine was present throughout the range of tHcy values, including the 'normal range' (5-15 $\mu \mathrm{mol} / 1)$.

\section{Secondary prospective study}

Recently, 587 Norwegian patients with angiographically confirmed CAD were followed prospectively for a median period of 4.6 years and during this time 64 patients died $(10.9 \%)$. They found a strong graded relationship between tHcy levels and overall mortality; levels were only weakly associated with the degree of $\mathrm{CAD}$, but more strongly associated with a previous history of myocardial infarction, left ventricular ejection fraction and serum creatinine. The association of tHcy with mortality remained strong, even when the effects of these and other 
potential aetiological factors were accounted for. As with other studies, the effect of the association with tHcy was seen throughout the range of thcy values $(P<0.02)$. If only those patients who died of CAD were included (50), the association with tHcy was even stronger (Nygard et al. 1997).

\section{Effect of sex and menopause on the relationship of thcy to vascular disease}

Since the majority of the foregoing studies have predominantly looked at the effect of raised tHcy in men, it is important to summarize the comparative evidence between women and men, and the effect of the menopause. Most studies have shown higher thcy levels in post- than in pre-menopausal women (Boers et al. 1983; Brattström et al. 1985; Wouters et al. 1995) but not all (Andersson et al. 1992a).

In a further study from the European Concerted Action Project, Verhoef and colleagues (1997) looked at 750 cases with vascular disease before the age of 60 years, compared with 800 controls. tHcy levels rose progressively with age in both sexes; and fasting levels were $15 \%$ (1.1-20) higher in men than in women, and in post methionine loading tests by $8 \%(4-13)$. After the menopause, tHcy levels were higher in women than men in post methionine loading tests, but not in fasting levels. However, the tHcy levels were unchanged after adjusting for vitamin levels and serum creatinine. In men, after adjusting for age and conventional risk factors, the OR for the association between tHcy and vascular disease were $1.5(1.2-1.8)$ in fasting samples and $1.3(1 \cdot 1-1.6)$ post methionine loading. The comparative values in women were $1.6(1.3-2.5)$ fasting and $1.6(1.2-2.0)$ post methionine loading. The association of tHcy levels with vascular disease was similar, whether the female subjects were pre- or postmenopausal. The authors concluded that tHcy is an independent risk factor for vascular disease in men, and both before and after the menopause in women.

\section{Pathogenesis of vascular disease related to hyperhomocysteinaemia}

The vascular disease associated with hyper-tHcy is related to endothelial dysfunction, smooth muscle proliferation and abnormalities of coagulation and related factors (reviewed by D'Angelo \& Selhub, 1997).

\section{Vascular endothelial dysfunction}

Endothelial cells express MTHFR but not betaine homocysteine methyl transferase (Wang et al. 1992). There is controversy as to whether they contain C $\beta S$ (Green \& Jacobsen, 1995). This is important because in C $\beta S$ deficiency endothelial cells certainly get damaged. If they do not have this enzyme, the damage must by done by extracellular rather than intracellular homocysteine in patients with hyper-tHcy. Patients with $C \beta S$ and MTHFR deficiency not only develop hyper-tHcy but also have endothelial cells that are peculiarly susceptible to damage induced by homocysteine (Wang et al. 1992). The reactivity of the sulphydryl group of homocysteine has been implicated. In the presence of NO and endothelium-derived relaxing factor, thiols react to form S-nitrosothiols which are potent vasodilatory and antiplatelet aggregation factors (Stamler et al. 1993). Under normal circumstances endothelial cells modulate the potential adverse effects of homocysteine by releasing endothelium-derived relaxing factor and forming S-NO-homocysteine. The adverse vascular effects of homocysteine 
may be due to inability to maintain S-NO formation as the homocysteine levels increase (Stamler et al. 1993). This in turn leads to the generation of superoxide anion radicals and hydrogen peroxide which inactivate NO and lead to endothelial cell damage (Loscalzo, 1996), causing platelet adhesion, induction of tissue factor and reduced plasminogen activation.

\section{Vascular smooth muscle proliferation}

Hyper-tHcy also causes vascular damage by enhancing proliferation and growth of vascular smooth muscle cells (Tsai et al. 1994), possibly induced by platelet factors (Harker et al. 1976).

\section{Coagulation abnormalities}

Homocysteine also enhances intravascular thrombosis. It induces tissue factor procoagulant activity by increasing tissue factor mRNA in endothelial cells, thus causing a promotion of the initiation of vascular coagulant mechanisms, possibly mediated by hydrogen peroxide (Fryer et al. (1993). tHcy also activates factors XII and IV and suppresses protein C (Rodgers \& Conn, 1990).

thcy inhibits the processing and secretion of von Willebrand factor from the endoplasmic reticulum of the endothelial cells, which suggests that intracellular transport of multiple endothelial cell proteins may be altered in patients with hyper-tHcy (Lentz \& Sadler, 1993) and could be a mechanism of altered endothelial cell resistance to thrombosis. For example, the modulation by homocysteine of tissue plasminogen activates binding to endothelial cell membrane receptors which impairs the antithrombotic properties of the blood vessel wall (Hajjar, 1993).

\section{Summary of current evidence that elevated thcy causes cardiovascular disease}

Taken as a whole the evidence from both retrospective and prospective case-control trials supports a primary association between tHcy and atherosclerotic vascular disease. The reasons why two of the early prospective trials (Stampfer et al. 1992; Alfthan et al. 1994) failed to show an association between tHcy and IHD, while two studies did (Arnesen et al. 1995; Wald et al. 1998), are discussed in detail elsewhere (Wald et al. 1998). When taken in conjunction with the studies showing a direct association between the degree of arterial disease and thcy (Malinow et al. 1995; Selhub et al. 1995; Konecky et al 1997) the evidence is persuasive. The recent publications showing regression of atheromatous plaques when treated with cobalamin, folate and PLP are particularly convincing (Peterson \& Spena, 1998).

It seems that disordered platelet function is primarily responsible for the development of atheromatous disease of the arterial endothelium, while abnormal coagulation and/or fibrinolysis produces thromboembolic disease.

\section{Hyperhomocysteinaemia due to defective enzymes causing impaired metabolism}

\section{Defects associated with cystathionine $\beta$-synthase}

This subject has been reviewed by D'Angelo \& Selhub (1997). The evidence suggests that being heterozygous for the $\mathrm{C} \beta \mathrm{S}$ gene defect does not enhance the likelihood of developing 
heart attacks or strokes (Mudd et al. 1995). Doppler studies on arterial disease have given conflicting results. Furthermore the prevalence of $C \beta S$ mutations is not elevated in CVD patient populations when compared with controls (Kluijtmans et al. 1996).

\section{Defects associated with dysfunction of methylene tetrahydrofolate reductase}

\section{Severe mutations of MTHFR}

Rare, but severe, mutations of the MTHFR which have been cloned and sequenced (Goyette et al. 1994, 1995) are associated with neurological abnormalities and severe vascular disease (Rosenblatt, 1995). Even among the heterozygous carriers they lead to premature death. However, these defects are too rare to account for the prevalence of mild hyper-tHcy present in the community.

\section{Thermolabile variant MTHFR C677T}

An unstable thermolabile variant form of this enzyme has also been described (Kang et al. 1988a). This enzyme was originally characterized by partial denaturation at $46^{\circ} \mathrm{C}$ for five minutes (van der Put et al. 1995). Its malfunction leads to moderately raised levels of tHcy (Kang et al. 1988a, 1991; Jacques et al. 1996; Harmon et al. 1996). This thermolabile variant was shown to be significantly associated with CHD (Kang et al. 1988a, 1991). A responsible gene has recently been isolated (Frosst et al. 1995) and the defect shown to be a C $\beta T$ mutation in the 677 nucleotide, which codes for an enzymic substitution of valine for alanine. Several studies have suggested that this polymorphism may be the only mutation that accounts for this thermolabile MTHFR (van der Put et al. 1995; Kluijtmans et al. 1996; Christensen et al. 1997). All studies showed distinct thermolability for the homozygous mutant genotype. The efficiency of the homozygous thermolabile mutant is around fifty percent of the homozygous wild type and the heterozygote was intermediate between the two. This is because the enzyme is deficient owing to its thermolability, rather than to malfunction of what enzyme remains (R.G. Matthews, pers. comm.).

A positive association between the presence of the MTHFR mutant and raised tHcy has been reported (Kang et al. 1991, 1993; Ma et al. 1996). However, it appears that the thcy level is elevated only in those subjects with low plasma folates (Harmon et al. 1996; Jacques et al. 1996; Ma et al. 1996).

The Hordaland homocysteine study (Guttormsen et al. 1996) screened 18043 subjects $40-67$ years old and found 67 cases with tHcy $\geqslant 40 \mu \mathrm{mol} / \mathrm{l}$. When compared with 329 controls, the cases had lower plasma folate and cobalamin levels and consumed less vitamin supplements. Homozygosity for the MTHFR C677T was present in $73.1 \%$ of cases and in $10.2 \%$ of controls. Two years later, 58 of the 67 cases were reinvestigated and 41 still had tHcy $>20 \mu \mathrm{mol} / \mathrm{l}, 92 \%$ of whom were homozygous for the MTHFR C677T mutant. This study suggests that the C677T mutant is strongly associated both with low plasma folate and high thcy.

A recent meta-analysis has shown that the prevalence of this defect varies in different communities; while being relatively uncommon in Africans (Delport et al. 1997), the homozygous form was present in 235 out of 2542 western Caucasian controls (9.2\%) (van der Put et al. 1997). 
The importance of the C677T variant is that its homozygous form is both relatively common in the normal population and has been reported to be associated with certain diseases. These include NTD and vascular disease, in particular CAD in some studies, but not in others.

\section{Neural tube defects and MTHFR C677T}

The association of the variant with NTD is perhaps its most convincing link to a clinical state. It has now been demonstrated by four separate groups (Ou et al. 1995; Van der Put et al. 1995; Whitehead et al. 1995; Papapetrou et al. 1996). However, it still accounts for only $13 \%$ of the attributable risk in the population (Whitehead et al. 1995). How the variant increases NTD risk is still to be determined; it may be by reducing the folate status in the embryo and perhaps also in the mother. This has recently been shown in normal individuals homozygous for the MTHFR C677T variant (Molloy et al. 1997).

The MTHFR C677T variant is associated with an increased tHcy and lower plasma (Harmon et al. 1996) and red cell (Molloy et al. 1997) folate. However, when mothers who were homozygous for the MTHFR C677T variant were excluded, there was no significant effect on the relationship of the remainder between NTD prevalence and maternal RCF levels (Molloy et al. 1998). This suggests that the primary effect of the variant is not so much to elevate thcy as to lower intracellular folate.

\section{Vascular disease and MTHFR C677T}

Vascular disease has also been associated with the homozygous C677T thermolabile enzyme (Kang et al. 1992; Frosst et al. 1995; Gallagher et al. 1996; Kluitjmans et al. 1996). This would seem likely, since MTHFR (C677T) produces a moderate rise in thcy (Engbersen et al. 1995; Harmon et al. 1996) which is a risk factor for cardiovascular, peripheral and CVD (see above). Gallagher and colleagues (1996) studied 111 patients with proven heart disease and 105 matched controls. The defective allele was higher in cases than controls (OR 1.6; $95 \% \mathrm{CI} \mathrm{1.1-}$ $2.4 ; \mathrm{P}=0.02$ ). Being homozygous for the MTHFR variant was $17 \%$ higher in cases compared with $7 \%$ in controls $(2.9 ; 1.2-7.2 ; \mathrm{P}=0.02)$ and thcy levels were significantly matched to disease status.

Other studies have challenged the view that there is any significant association between the MTHFR C677T and CVD, in Australia (Wilcken et al. 1996), the Netherlands (van Bockxmeer et al. 1997), USA (Ma et al. 1996) and Britain (Adams et al. 1996), even to the extent of an outright denial of any relationship (Wilcken, 1997). The increased tendency to CAD in subjects with raised thcy may include inter alia an increased tendency to atheroma and an enhanced liability to thrombosis. Thus, the criteria for choosing cases and controls may be of fundamental importance. Kang and coworkers (1991), in choosing their control group, excluded subjects with any history of thrombosis, whereas Adams and coworkers (1996) compared their patients with controls from the general population, regardless of whether or not they had had a previous vascular event.

Furthermore, the MTHFR C677T variant is associated with a raised tHcy only in the presence of low folate levels (Harmon et al. 1996; Jacques et al. 1996; Ma et al. 1996). At folate levels in the middle and upper quartiles, the prevalence of the genotypes did not vary. tHcy was only significantly elevated in homozygous subjects in the low folate group. This was 
especially true for men under 60 years old (Ma et al. 1996). The MTHFR C677T variant is therefore likely to be associated with vascular disease only in communities with a low dietary folate intake (Scott \& Weir, 1996). Ma and colleagues (1996) found a nonsignificant increase in the risk of myocardial infarct among those with the MTHFR C677T variant in those who had a low folate level and were under 60 years old; however, the number with low folate was small and the CI was wide.

The differences between the findings of Kang and co-workers (1988a) when assessing the frequency of the thermolabile enzyme in patients with CVD which were very significant, and the findings of the majority of studies of the MTHFR C677T variant which found a minimal association and only in situations of folate deficiency, may relate to the presence of other as yet undiscovered genetic variants of the MTHFR enzyme. It is also important to remember that tHcy is only the marker of an intracellular event. While excess homocysteine may be produced in all cells of the body when severe vitamin B nutritional deficiency or severe mutant defects of MTHFR occur (Mudd et al. 1995), it is possible that the raised tHcy associated with the C677T variant reflects disordered metabolism only in certain specific organs such as the liver but not in the endothelial cells lining the blood vessels. It is quite possible that defective enzyme activity might manifest itself only in cells with a high flux of folate through the MTHFR enzyme, i.e. cells with a low turnover and a high requirement for SAM mediated methyl groups (Weir \& Scott, 1995).

The MTHFR C677T is associated with low serum folate in most (Harmon et al. 1996), though not all, (Kluijtmans et al. 1996) studies. Some groups found that the RCF level was high (van der Put et al. 1995), while others found that it was low (Molloy et al. 1997). There are currently two methods used to measure RCF, the radiometric assay (Levine, 1993) and the biological assay using Lactobacillus casei (Molloy \& Scott, 1998). The radiometric assay is known to measure RCF at lower levels overall than the microbiological assays (McGown et al. 1978; Gunter et al. 1996). However, when subjects were divided into those homozygous for the C677T variant (TT), heterozygous (CT) or homozygous wildtype (CC), it was found that the radiometric assay gave results which were consistently and significantly higher than the microbiological assay in the TT group, while the levels in the CT and CC groups were significantly lower as expected (Molloy et al. 1998). This strongly suggests that the radiometric assay is measuring a biologically inactive folate compound or degradation product in the TT group, that cannot be measured by the microbiological assay. Whatever its nature, it could be of relevance to the pathogenesis of hyper-tHcy seen in homozygous MTHFR C677T subjects (Molloy et al. 1998). Folate is required to stabilize the function of MTHFR (Frosst et al. 1995), which is supported by the finding that folic acid therapy normalizes hyper-tHcy induced by the thermolabile MTHFR enzyme (Kang et al. 1988a,b). It may be that the biologically inactive folate compound in some way destabilizes the function of methylene reduction producing hyper-tHcy. It is also possible that the inactive compound represents a catabolic product of folate and that the TT group is in some way more at risk of intracellular folate catabolism.

Other reasons why the hyper-tHcy found in homozygous carriers of the MTHFR C677T variant was not associated with an increased prevalence of CAD may relate to smoking and the prevalence of high blood pressure. Hypertension, an independent risk factor for myocardial infarction, was found to correlate positively with tHcy levels (Levenson et al. 1994; ChasanTaber et al. 1996; Graham et al. 1997). Smoking also correlated with tHcy in the European cohort study (Graham et al. 1997). 


\section{Clinical conditions associated with hyperhomocysteinaemia \\ and coronary artery disease}

\section{Chronic renal failure (CRF)}

Hyper-tHcy is a common finding in patients with CRF in whom tHcy tends to be in excess of $25 \mu \mathrm{mol} / 1$ (Wilcken et al. 1980; Bostom et al. 1996a; Dennis \& Robinson, 1996). Since in CRF cardiovascular disease accounts for more than a third of all deaths (Parfrey, 1993), tHcy has been under close scrutiny as a possible cause (Bachmann et al. 1995). The important point is that dialysis, while reducing blood urea and creatinine levels, has little effect on tHcy. The resulting levels of tHcy, hyperfibrinogenaemia and lipoprotein (a) excess may well account for the high incidence of vascular disease in CRF patients (Bostom et al. 1996b). It is also well known that plasma folate concentrations show a significant negative correlation with tHcy levels, both before and after dialysis $(\mathrm{r}=-0.53, \mathrm{P}<0.003$; and $\mathrm{r}=-0.58, \mathrm{P}<0.001$ respectively). This was also true for RCF pre- and post-dialysis and occurred despite what appeared to be an adequate dietary folate intake (Bostom et al. 1996a; Tamura et al. 1996). Raised thcy is usually easily reduced by taking vitamin B supplements; however, it appears that CRF patients require higher than normal levels of folate to reduce tHcy levels and prevent the associated vascular complications (Bostom et al. 1996a; Robinson et al. 1997). As reviewed by Perna and colleagues (1996), raised thcy levels in CRF may be caused by reduced urinary excretion, however, the total amounts of tHcy excreted are trivial when considered against the total quantity produced by the body. The main reason probably relates to decreased renal metabolism, since the tHcy levels are lower in the renal vein than the renal artery (Bostom et al. 1995; Amadottir et al. 1996).

\section{Connective tissue disease}

In systemic lupus erythematosus it has been shown prospectively that elevated tHcy relates to the risk of stroke and thromboembolic events (Petri et al. 1996). In this study 337 systemic lupus erythematosus patients were followed for a mean of 4.8 years. Twenty-nine patients had a stroke and 31 had arterial thrombotic events. tHcy was significantly associated with the thrombotic events (OR 3.74; $95 \%$ CI $1.96-7.32 ; \mathrm{P}=0.001)$ and with stroke $(2.24 ; 1.22-4.13$; $\mathbf{P}=0.001$ ). When established risk factors were adjusted, thcy remained an independent risk factor for both thrombosis and stroke.

In rheumatoid arthritis (RA) tHcy was higher than control values in both the fasting and post methionine challenge tests (Roubenoff et al. (1997). Paradoxically, the patients on treatment with methotrexate had normal thcy values. Roubenoff and colleagues suggested that the raised tHcy in their RA patients were associated with low plasma concentrations of PLP. It would also explain their high incidence of cardiovascular mortality.

We have found similar results in RA patients treated with a variety of different therapies. In particular, methotrexate was found to lower tHcy, but gold therapy was associated with high values (Mahmud et al. 1998a). 


\section{Diabetes}

Paradoxically Type I insulin dependent diabetes mellitus was associated with lower tHcy than in controls. This was true for males and females (Robillon et al. 1994).

We have confirmed these findings, although the rate of rise of the thcy levels with age in both sexes is quicker in patients with insulin dependent diabetes mellitus than in normal controls. This may indicate that the increased rate of renal perfusion in insulin dependent diabetes mellitus may initially lead to a more rapid rate of thcy metabolism by the kidneys, which may deteriorate with age (C.C. Cronin et al. 1996).

It has also been reported that the prevalence of the MTHFR C677T variant is higher in diabetes with than without retinopathy (Neugebauer et al. 1997). It was suggested that this might have pathogenic significance.

\section{Chronic inflammatory bowel disease}

Thromboembolic disease is common in chronic inflammatory bowel disease (Talbot et al. 1986), which may relate to a hypercoagulable state (Edwards et al. 1987). A recent study has demonstrated that prothrombotic agents are not involved (Jackson et al. 1997); however, higher thcy is (Andus et al. 1996, Mahmud et al. 1998). The hyper-tHcy is especially associated with the MTHFR C677T variant (Molloy et al, 1997; Mahmud et al. 1998b).

\section{Conclusions}

There is now very strong evidence that tHcy correlates with increased risk of cardiovascular disease, stroke and a wide range of other thromboembolytic conditions. It is clear from some of these studies, particularly the two definitive prospective studies of Amesen et al. (1995) and Wald et al. (1998), that this risk associated with homocysteine is continuous right down to the lowest levels encountered in plasma. The absence of a plateau suggests that there is increased benefit from lowering homocysteine, not just in the abnormally high range, but in what would formerly have been considered the normal range. This begs the question of the probable percentage of the population who have tHcy that can be lowered and whether such lowering could be achieved by nutritional means. It seems clear that most people and particularly the elderly have thcy that can be reduced principally by the addition of folic acid to the diet (Selhub et al. 1993). Vitamin $B_{6}$ and/or $B_{12}$ could also contribute. This applies to populations with folate intakes not significantly below the existing recommended dietary allowance in the UK and the USA of $200 \mu \mathrm{g}$ food folate/d. Even in younger apparently well fed adult males the majority have tHcy that could be reduced signifcantly by small increased levels of dietary folic acid (100 to $200 \mu \mathrm{g} / \mathrm{d}$ ) (Ward et al. 1997). This, together with evidence that thcy is related to risk of CVD and stroke without an apparent plateau, suggests that it may be desirable to raise the recommended dietary allowance (recommended nutrient intake) for folate. We suggest that because of poor bioavailability and perhaps more importantly the poor stability of the natural forms of folate in food, this objective will not easily be achieved by an increase in food folates. The alternative is to fortify food with a stable and bioavailable synthetic form, namely folic acid. This seems the only realistic way of optimally lowering homocysteine in most individuals and populations. 


\section{References}

Adams, M., Smith, P.D., Martin, D., Thompson, J.R., Lodwick, D. \& Samani, N.J. (1996). Genetic analysis of thermolabile methylenetetrahydrofolate reductase as a risk factor for myocardial infarction. QJM: Monthly Journal of the Association of Physicians 89, 437-444.

Alfthan, G., Aro, A. \& Gey, K.F. (1997). Plasma homocysteine and cardiovascular disease mortality. Lancet $349,397$.

Alfthan, G., Pakkanen, J., Jaubirmen, M. et al. (1994). Relation of serum homocysteine and lipoprotein(a) concentrations to atherosclerotic disease in a prospective Finnish population based study. Atherosclerosis 106, 9-16.

Allen, R.H., Stabler, S.P., Savage, D.G. \& Lindenbaum, J. (1993). Metabolic abnormalities in cobalamin (vitamin B 12 ) and folate deficiency. FASEB Journal 7, 1344-1353.

Andersson, A., Brattström, L., Israelsson, B., Isaksson, A., Hamfelt, A. \& Hultberg, B. (1992a). Plasma homocysteine before and after methionine loading with regard to age, gender and menopausal status. European Journal of Clinical Investigation 22, 79-87.

Andersson, A., Hultberg, B., Brattström, L. \& Isaksson, A. (1992b). Decreased serum homocysteine in pregnancy. European Journal of Clinical Chemistry \& Clinical Biochemistry 30, 377-379.

Andus, T., Mollens, C., Geissler, A., Vogl, D., Gross, V., Schmitz, G., Henna, W. \& Scholmenick, J. (1996). Elevated homocysteine concentrations in sera of patients with inflammatory bowel disease. Gastroenterology 110, A855(i).

Araki, A. \& Sako, Y. (1987). Determination of free and total homocysteine in human plasma by high performance liquid chromatography with fluorescence detection. Joumal of Chromatography: Biomedical Applications 422, 43-52.

Amadottir, M., Hultberg, B., Nilsson-Ehle, P. \& Thysell, H. (1996). The effect of reduced glomerular filtration rate on plasma total homocysteine concentration. Scandinavian Joumal of Clinical Laboratory Investigation 56, 41-46.

Arnesen, E., Refsum, H., Bonaa, K.H., Ueland, P.M., Forde, O.H. \& Nordrehaug, J.E. (1995). Serum total homocysteine and coronary heart disease. International Journal of Epidemiology 24, 704-709.

Aronson, D.C., Onkenhout, W., Raben, A.M.T.J., Oudenhoven, L.F.I.J., Brommer, E.J.P. \& van Bockel, J.H. (1994). Impaired homocysteine metabolism: a risk factor in young adults with atherosclerotic arterial occlusive disease of the leg. British Journal of Surgery 81, 1114-1118.

Bachmann, J., Tepel, M., Raidt, H., Riezler, R., Graefe, U., Langer, K. \& Zidek, W. (1995). Hyperhomocysteinemia and the risk for vascular disease in hemodialysis patients. Journal of the American Society of Nephrology 6, 121 125.

Blakley, R.L. (1969). The Biochemistry of Folic Acid and Related Pteridines (Frontiers in Biology, vol. 13). Amsterdam: North Holland.

Boers, G.H.J., Smals, A.G., Trijbels, F.J., Leermakers, A.I. \& Kloppenborg, P.W. (1983). Unique efficiency of methionine metabolism in premenopausal women may protect against vascular disease in the reproductive years. Journal of Clinical Investigation 72, 1971-1976.

Boers, G.H.J., Smals, A.G.H., Trijbels, F.J.M., Fowler, B., Bakkeren, J.A.J.M., Schoonderwaldt, H.C., Kleijer, W.J. \& Kloppenborg, P.W.C. (1985). Heterozygosity for homocysteinuria in premature peripheral and cerebral occlusive arterial disease. New England Journal of Medicine 313, 709-715.

Bostom, A.G., Brosnan, J.T., Hall, B., Nadeau, M.R. \& Selhub, J. (1995). Net uptake of plasma homocysteine by the rat kidney in vivo. Atherosclerosis 116, 59-62.

Bostom, A.G., Shemin, D., Lapane, K.L., Nadeau, M.R., Sutherland, P., Chan, J., Rozen, R., Yoburn, D., Jacques, P.F., Selhub. J. \& Rosenberg, I.H. (1996a). Folate status is the major determinant of fasting total plasma homocysteine levels in maintenance dialysis patients. Atherosclerosis 123, 193-202.

Bostom, A.G., Shemin, D., Lapane, K.L., Sutherland, P., Nadeau, M.R., Wilson, P.W., Yobam, D., Bausserman, L., Tofler, G., Jacques, P.F., Selhub, J. \& Rosenberg, I.H. (1996b). Hyperhomocysteinaemia, hyperfibrinogenaemia and lipoprotein (a) excess in maintenance dialysis patients: a matched case-control study. Atherosclerosis 125, 91-101.

Boushey, C.J., Beresford, S.A.A., Omenn, G.S. \& Motulsky, A.G. (1995). A quantitative assessment of plasma homocysteine as a risk factor for vascular disease: probable benefits of increasing folic acid intake. JAMA: Jourmal of the American Medical Association 274, 1049-1057.

Brattström, L., Englund, E. \& Brun, A. (1987). Does Down syndrome support homocysteine theory of arteriosclerosis? Lancet I, 391-392.

Brattström, L.E., Hardebo, J.E. \& Hultberg, B.L. (1984). Moderate homocysteinemia-a possible risk factor for arteriosclerotic cerebrovascular disease. Stroke 15, 1012-1016.

Brattström, L.E., Hultberg, B.L. \& Hardebo, J.E. (1985). Folic acid responsive post-menopausal homocysteinemia. Metabolism 34, 1073-1077.

Brattström, L.E., Israelsson, B., Jeppsson, J.O. \& Hultberg, B.L. (1988). Folic acid-an innocuous means to reduce plasma homocysteine. Scandinavian Journal of Clinical and Laboratory Investigation 48, 215-221.

Brattström, L., Israelsson, B., Norrving, B., Bergqvist, D., Thörne, J., Hultberg, B. \& Hamfelt, A. (1990). Impaired homocysteine metabolism in early-onset cerebral and peripheral occlusive arterial disease: effects of pyrodoxine and folic acid treatment. Atherosclerosis $81,51-60$.

Brattström, L., Israelsson, B., Tengborn, L. \& Hultberg, B. (1989). Homocysteine, factor VII and antithrombin III in subjects with different gene dosage of cystathionine- $\beta$-synthase. Joumal of Inherited Metabolic Disease 12, $475-482$.

Brattström, L., Lindgren, A., Israelsson, B., Andersson, A. \& Hultberg, B. (1994). Homocysteine and cysteine: determinants of plasma levels in middle-aged and elderly subjects. Journal of Internal Medicine 236, 633-641. 
Brattström, L., Lindgrten, A., Israelsson, B., Malinow, M.R., Norrving. B., Upson, B. \& Hamfelt, A. (1992). Hyperhomocysteinaemia in stroke: prevalence, cause, and relationships to type of stroke and stroke risk factors. European Journal of Clinical Investigation 22, 214-221.

Carson, N.A.J. \& Neill, D.W. (1962). Metabolic abnormalities detected in a survey of mentally backward individuals in Northern Ireland. Archives of Disease in Childhood 37, 505-513.

Chadefaux, B., Ceballos, I., Hamet, M., Coude, M., Poissonnier, M., Kamoun, P. \& Allard, D. (1988). Is absence of atheroma in Down syndrome due to decreased homocysteine levels? Lancet 2, 741.

Chambers, J.C., McGregor, A., Jean-Marie, J. \& Koower, J.S. (1998). Acute hyperhomocysteinaemia and endothelial dysfunction. Lancet 351, 36-37.

Chasan-Taber, L., Selhub, J., Rosenberg, I.H., Malinow, M.R., Terry, P., Tishler, P.V., Willet, W., Hennekens, C.H. \& Stampfer, M.J. (1996). A prospective study of folate and vitamin $B_{6}$ and risk of myocardial infarction in US physicians. Journal of the American College of Nutrition 15, 136-143.

Christensen, B., Frosst, P., Lussier-Cacan, S., Selhub, J., Goyette, P., Rosenblatt, D., Genest, J. \& Rozen, R. (1997). Correlation of a common mutation in the methylene tetrahydrofolate reductase (MTHFR) gene with plasma homocysteine in patients with premature coronary artery disease. Arteriosclerosis, Thrombosis and Vascular Biology 17, 569-571.

Corrales, F., Gimenez, A., Alvarez, L., Caballeria, J., Pajares, M.A., Andreu, H., Pares, A., Mato, J.M. \& Rodes, J. (1992). S-adenosylmethionine treatment prevents carbon tetrachloride-induced S-adenosylmethionine synthetase inactivation and attenuates liver injury. Hepatology 16, 1022-1027.

Corrales, F., Ochoa, P., Rivas, C., Martin-Lomas, M., Mato, J.M. \& Pajares, M.A. (1991). Inhibition of glutathione synthesis in the liver leads to S-adenosyl-L-methionine synthetase reduction. Hepatology 14, 528-533.

Cronin, C.C., McPartlin, J.M., Barry, D.G., Ferris, B., Scott, J.M. \& Weir, D.G. (1996). Plasma total homocyst(e)ine concentration and micro-vascular complications in insulin-dependent (Type 1) diabetes mellitus. Diaberic Medicine $13,51$.

Cuskelly, G.J., McNulty, H. \& Scott, J.M. (1996). Effect of increasing dietary folate on red cell folate: implications for prevention of neural tube defects. Lancet 347, 657-659.

Daly, L.E., Kirke, P.N., Molloy, A., Weir, D.G. \& Scott, J.M. (1995). Folate levels and neural tube defects. Implications for prevention. JAMA: Joumal of the American Medical Association 274, 1698-1702.

Daly, S., Mills, J.L., Molloy, A.M., Conley, M., Lee, Y.J., Kirke, P.N., Weir, D.G. \& Scott, J.M. (1997). Minimum effective dose of folic acid for food fortification to prevent neural-tube defects. Lancet 350, 1666-1669.

D'Angelo, A. \& Selhub, J. (1997). Homocysteine and thrombotic disease. Blood 90, 1-11.

De la Haba, G. \& Cantoni, G.L. (1959). The enzymatic synthesis of S-adenosyl-L-homocysteine from adenosine and homocysteine. Joumal of Biological Chemistry 234, 603-608.

Delport, R., Ubbink, J.B., Vermaak, W.J.H., Rossouw, H., Becker, P.J. \& Joubert, J. (1997). Hyperhomocysteinaemia in black patients with cerebral thrombosis. QJM: Monthly Joumal of the Association of Physicians 90, 635-639.

den Heijer, M.D., Koster, T., Blom, H.J., Bos, G.M.J., Briet, E., Reitsma, P.H., Van den Broucke, J.P. \& Rosendaal, F.R. (1996). Hyperhomocysteinemia as a risk factor for deep vein thrombosis. New England Journal of Medicine 334, 759-762.

Department of Health (1991). Dietary Reference Values for Food and Energy and Nutrients for the United Kingdom (Report on Health and Social Subjects no. 41). London: HMSO.

Dennis, V.W. \& Robinson, K. (1996). Homocysteinaemia and vascular disease in end stage renal disease. Kidney Intemational Suppl. 57, S11-17.

Drummond, J.T. \& Matthews, R.G. (1994). Nitrous oxide inactivation of cobalamin-dependent methionine synthase from Escherichia coli: characterization of the damage to the enzyme and prosthetic group. Biochemistry 33, 37423750.

Dudman, N.P.B., Wilcken, D.E.L., Wang, J., Lynch, J.F., Macey, D. \& Lundberg, P. (1993). Disordered methionine/ homocysteine metabolism in premature vascular disease. Its occurrence, cofactor therapy and enzymology. Arteriosclerosis and Thrombosis 13, 1253-1260.

Edwards, R.L., Levine, J.B., Green, R., Duffy, M., Mathews, E., Brande, W. \& Rickles, F.R. (1987). Activation of blood coagulation in Crohn's disease. Increased plasma fibrinopeptide A levels and enhanced generation of monocyte tissue factor activity. Gastroenterology 92, 329-337.

Engbersen, A.M.T., Franken, D.G., Boers, G.H.J., Stevens, E.M.B., Trijbels, F.J.M. \& Blom, H.J. (1995). Thermolabile 5,10-methylenetetrahydrofolate reductase as a cause of mild hyperhomocysteinemia. American Joumal of Human Genetics 56, 142-150.

Fenton, W.A. \& Rosenberg, L.E. (1989). Inherited disorders of cobalamin transport and metabolism. In The Metabolic Basis of Inherited Disease, p. 2065 [C.R. Scriver, A.L. Beaudet, W.S. Sly and D. Valle, editors]. New York: McGraw-Hill.

Finkelstein, J.D. (1990). Methionine metabolism in mammals. Journal of Nutritional Biochemistry 1, $228-237$.

Frosst, P., Blom, H.J., Milos, R., Goyette, P., Sheppard, C.A., Matthews, R G., Boers, G.J.H., den Hejjer, M., Kluijtmans, L.A.J., Van den Heuvel, L.P. \& Rozen, R. (1995). A candidate genetic risk factor for vascular disease: a common mutation in methylenetetrahydrofolate reductase. Nature Genetics 10, 111-113.

Fryer, R.H., Wilson, B.D., Gubler, D.B., Fitzgerald, L.A. \& Rodgers, G.M. (1993). Homocysteine, a risk factor for premature vascular disease and thrombosis, induces tissue factor activity in endothelial cells. Arteriosclerosis and Thrombosis 13, 1327-1333. 
Gallagher, P.M., Meleady, R., Shields, D.S., Tan, K.S., McMaster, D., Rozen, R., Evans, A., Graham, I.M. \& Whitehead, A.S. (1996). Homocysteine and risk of premature coronary heart disease: evidence for a common gene mutation. Circulation 94, 2154-2158.

Gerritsen, T., Vaughn, J.G. \& Waisman, H.A. (1962). The identification of homocystine in the urine. Biochemical and Biophysical Research Communications 9, 493-496.

Glueck, C.J., Shaw, P., Lang, J.E., Tracy, T., Sieve-Smith, L. \& Wang, Y. (1995). Evidence that homocysteine is an independent risk factor for atherosclerosis in hyperlipidemic patients. American Journal of Cardiology 75, $132-136$.

Goyette, P., Frosst, P., Rosenblatt, D.S. \& Rozen, R. (1995). Seven novel mutations in the methylenetetrahydrofolate reductase gene and genotype/phenotype correlations in severe methylenetetrahydrofolate reductase deficiency. American Journal of Human Genetics 56, 1052-1059.

Goyette, P., Summer, J.S., Milos, R., Duncan, A.M.V., Rosenblatt, D.S., Matthews, R.G. \& Rozen, R. (1994). Human methylenetetrahydrofolate reductase: isolation of cDNA, mapping and mutation identification. Nature Genetics 7 , $195-200$.

Graham, I.M., Daly, L.E., Refsum, H.M., Robinson, K., Brattström, L.E., Ueland, P.M., Paima-Reis, R.J. et al. (1997). Plasma homocysteine as a risk factor for vascular disease. JAMA: Joumal of the American Medical Association 277, 1775-1781.

Green, R. \& Jacobsen, D.W. (1995). Clinical implications of hyperhomocysteinaemia. In Folate in Health and Disease, pp. 75-122 [Lynn Bailey, editor]. New York: Marcel Dekker.

Gregory, J.F. (1995). The bioavailability of folate. In Folate in Health and Disease, pp. 195-236 [Lynn B. Bailey, editor]. New York: Marcel Dekker.

Gunter, E.W., Bowman, B.A., Caudill, S.P., Twite, D.B., Adams, M.J. \& Sampson, E.J. (1996). Results of an international round robin for serum and whole blood folate. Clinical Chemistry 42, 1689-94.

Guttormsen, A.B., Ueland, P.M., Nesthus, I., Nygard, O., Schneede, J., Vollset, S.E. \& Refsum, H. (1996). Determinants and vitamin responsiveness of intermediate hyperhomocysteinemia $(<40 \mu \mathrm{mol} / \mathrm{liter})-$ the Hordaland homocysteine study. Joumal of Clinical Investigation 98, 2174-2183.

Hajjar, K.A. (1993). Homocysteine-induced modulation of tissue plasminogen activator binding to its endothelial cell membrane receptor. Journal of Clinical Investigation 91, 2873-2879.

Harker, L.A., Ross, R., Stichter, S.J. \& Scott, C.R. (1976). Homocystine-induced arteriosclerosis. The role of endothelial cell injury and platelet response in its genesis. Journal of Clinical Investigation 58, 731-741.

Harmon, D.L., Woodside, J.V., Yarnell, J.W.G., McMaster, D., Young, I.S., McCrum, E.E., Gey, K.F., Whitehead, A.S. \& Evans, A.E. (1996). The common 'thermo-labile' variant of methylene tetrahydrofolate reductase is a major determinant of mild hyperhomocysteinaemia. $Q J M$ : Monthly Journal of the Association of Physicians 89, $571-577$.

Jackson, L.J., O'Gorman, P.J., O'Connell, J., Cronin, C.C., Cotter, K.P. \& Shanahan, F. (1997). Thrombosis in inflammatory bowel disease: clinical setting, procoagulant profile and factor V. QJM: Monthly Journal of the Association of Physicians $\mathbf{9 0}, 183-188$.

Jacob, R.A., Wu, M.M., Henning, S.M. \& Swendseid, M.E. (1994). Homocysteine increases as folate decreases in plasma of healthy men during short term dietary folate and methyl group restriction. Joumal of Nutrition 124, 10721080.

Jacques, P.F., Bostom, A.G., Williams, R.R., Ellison, R.C., Eckfeldt, J.H., Rosenberg, I.H., Selhub, J. \& Rozen, R. (1996). Relation between folate status, a common mutation in methylenetetrahydrofolate reductase and plasma homocysteine concentrations. Circulation 93, 7-9.

Joosten, E., van den Berg, A., Riezler, R., Naurath, H.J., Lindenbaum, J., Stabler, S.P. \& Allen, R.H. (1993), Metabolic evidence that deficiencies of vitamin $B_{12}$ (cobalamin), folate and vitamin $B_{6}$ occur commonly in elderly people. American Joumal of Clinical Nutrition 58, 468-476.

Kahn, H.A. (1966). The Dorn study of smoking and mortality among US veterans: report on eight and one-half years of observation. National Cancer Institute Monograph 19, 1-125.

Kang, S.-S., Passen, E.L., Ruggie, N., Kong, P.W.K. \& Sora, H. (1993). Thermolabile defect of methylenetetrahydrofolate reductase in coronary artery disease. Circulation 88, 1463-1469.

Kang, S.-S., Wong, P.W.K. \& Malinow, M.R. (1992). Hyperhomocyst(e)inemia as a risk factor for occlusive vascular disease. Annual Review of Nutrition 12, 279-298.

Kang, S.-S., Wong, P.W.K., Susmano, A., Sora, J., Nonusis, M. \& Ruggie, N. (1991). Thermolabile methylenetetrahydrofolate reductase: an inherited risk factor for coronary artery disease. American Journal of Human Genetics 48. 536-545.

Kang, S.-S., Wong, P.W.K., Zhou, J. \& Cook, H.Y. (1986). Preliminary report: total homocyst(e)ine in plasma and amniotic fluid of pregnant women. Metabolism 35, 889-891.

Kang, S.-S., Wong, P.W.K., Zhou, J., Sora, J., Lessick, M., Ruggie, N. \& Grcevich, G. (1988a). Thermolabile methylenetetrahydrofolate reductase in patients with coronary artery disease. Metabolism 37, 611-613 (b).

Kang, S.-S., Zhou, J., Wong, P.W.K., Kowalisyn, J. \& Strokosch, G. (1988b). Intermediate homocysteinaemia: a thermolabile variant of methylenetetrahydrofolate reductase. American Journal of Human Genetics 43, 414-421 (a).

Kelly, P., McPartlin, J., Goggins, M., Weir, D.G. \& Scott, J.M. (1997). Unmetabolized folic acid in serum: acute studies in subjects consuming fortified food and supplements. American Joumal of Clinical Nutrition 65, 1790-1795.

Kirke, P.N., Molloy, A.M., Daly, L.E., Burke, H., Weir, D.G. \& Scott, J.M. (1993). Matemal plasma folate and vitamin $\mathrm{B}_{12}$ are independent risk factors for neural tube defects. Quarterly Joumal of Medicine 86, 703-708. 
Kluijtmans, L.A.J., van den Heuvel, L.P.W.J., Boers, G.H.J., Frosst, P., Stevens, E.M.B., van Oost, B.A., den Heijer, M., Trijbels, F.J.M., Rosen, R. \& Blom, H.J. (1996). Molecular genetic analysis in mild hyperhomocysteinemia: a common mutation in the methylenetetrahydrofolate reductase gene is a genetic risk factor for cardiovascular disease. American Joumal of Human Genetics 58, 35-41.

Konecky, N., Malinow, R., Tunick, P.A., Freedberg, R.S., Rosenzweig, B.P., Katz, E.S., Hees, D.L., Upson, B., Leung, B., Perez, J. \& Kronzon, I. (1997). Correlation between plasma homocysteine and aortic atherosclerosis. American Heart Journal 133, 534-540.

Kraus, J.P. (1994). Molecular basis of phenotype expression in homocysteinuria. Journal of Inherited Metabolic Disease 17, 383-390.

Kraus, J.P., Le, K., Swaroop, M., Ohura, T., Tahara, T., Rosenberg, L.E., Roper, M.D. \& Kozich, V. (1993). Human cystathionine $\beta$-synthase cDNA: sequence, alternative splicing and expression in cultured cells. Human Molecular Genetics 2, 1633-1638.

Kutzbach, C. \& Stokstad, E.L.R. (1971). Mammalian methylenetetrahydrofolate reductase. Partial purification, properties, and inhibition by S-adenosylmethionine. Biochimica et Biophysica Acta 250, 459-477.

Landgren, F., Israelsson, B., Lindgren, A., Hultberg, B., Andersson, A. \& Brattström, L. (1995). Plasma homocysteine in acute myocardial infarction: homocysteine-lowering effect of folic acid. Journal of Intemal Medicine 237, $381-388$.

Law, M.R., Wald, N.J. \& Thompson, S.G. (1994). By how much and how quickly does reduction in serum cholesterol concentration lower risk of ischaemic heart disease? British Medical Journal 308, 367-372.

Lentz, S.R. \& Sadler, J.E. (1993). Homocysteine inhibits von Willebrand factor processing and secretion by preventing transport from the endoplasmic reticulum. Blood 81, 683-689.

Levenson, J., Malinow, M.R., Giral, P.H., Razavian, M. \& Simon, A. (1994). Increased homocysteine levels in human hypertension. Journal of Hypertension 12(Suppl. 3), S74.

Levine, S. (1993). Analytical inaccuracy for folic acid with a popular commercial vitamin B12/ folate kit. Clinical Chemistry 39, 2209-2210.

Loscalzo, J. (1996). The oxidant stress of hyperhomocyst(e)inemia. Journal of Clinical Investigation 98, 5-7.

Ma, J., Stampfer, M.J., Hennekens, C.H., Frosst, P., Selhub, J., Horsford, J., Malinow, M.R., Willett, W.C. \& Rosen, R. (1996). Methylenetetrahydrofolate reductase polymorphism, plasma folate, homocysteine and risk of myocardial infarction in US physicians. Circulation 94, 2410-2416.

McCully, K.S. (1969). Vascular pathology of homocysteinuria: implications for the pathogenesis of arteriosclerosis. American Journal of Pathology 56, $111-128$.

McCully, K.S. \& Wilson, R.B. (1975). Homocysteine theory of arteriosclerosis. Atherosclerosis 22, $215-227$.

McGown, E.L., Lewis, C.M., Dong, M.H. \& Sauberlich, H.E. (1978). Results with commercial radioassay kits compared with microbiological assay of folate in serum and whole blood. Clinical Chemistry 24, 2186-2191.

McKeever, M.P., Weir, D.G., Molloy, A. \& Scott, J.M. (1991). Betaine-homocysteine methyltransferase: organ distribution in man, pig and rat, and subcellular distribution in the rat. Clinical Science 81, 551-556.

Mahmud, N., Donnelly, S., Molloy, A., McPartlin, J., Casey, E.B., Scott, J. \& Weir, D.G. (1998a). Plasma homocysteine is raised in patients with rheumatoid arthritis independent of methylene tetrahydrofolate reductase genotype. British Journal of Rheumatology 37, A154.

Mahmud, N., Molloy, A., McPartlin, J., Scott, J.M. \& Weir, D.G. (1998b). Homozygosity for methylene reductase C677T variant is associated with low folate and hyperhomocysteinaemia in inflammatory bowel disease patients: important clinical complications. Gastroenterology 114, G4221.

Malinow, M.R., Duell, P.B., Hess, D.L. et al. (1998). Reduction in plasma homocysteine levels by breakfast cereal fortified with folic acid in patients with coronary heart disease. New England Joumal of Medicine 338, $1009-1015$.

Malinow, M.R., Levenson, J., Giral, P., Nieto, F.J., Razavian, M., Segond, P. \& Simon, A. (1995). Role of blood pressure, uric acid and hemorheological parameters on plasma homocyst(e)ine concentration. Atherosclerosis 114, 175-183.

Malinow, M.R., Nieto, F.J., Szklo, M., Chambless, L.E. \& Bond, G. (1993). Carotid artery intimal medial wall thickening and plasma homocyst(e)ine in asymptomatic adults. The Atherosclerosis Risk in Communities Study. Circulation 87, 1107-1113.

Malinow, M.R., Sexton, G., Averbuch, M., Grossman, M., Wilson, D. \& Upson, B. (1990). Homocysteinaemia in daily practice: levels in coronary artery disease. Coronary Artery Disease 1, 215-220.

Matthews, R.G. (1984). Methionine metabolism in folate and pterins. In Chemistry and Biochemistry of Folates, vol. 1, pp. 497-553 [R.L. Blakley and S.J. Benkovic, editors]. New York: Wiley \& Sons.

Matthews, R.G. \& Haywood, B.J. (1979). Inhibition of pig liver methylenetetrahydrofolate reductase by dihydrofolate: some mechanistic and regulatory implications. Biochemistry 18, 4845-4851.

Mayer, E.L., Jacobsen, D.W. \& Robinson, K. (1996). Homocysteine and coronary atherosclerosis. Journal of the American College of Cardiology 27, 517-527.

Molloy, A.M., Daly, S., Mills, J.L., Kirke, P.N., Whitehead, A.S., Ramsbottom, D., Conley, M.R., Weir, D.G. \& Scott, J.M. (1997). Thermolabile variant of 5,10-methylenetetrahydrofolate reductase associated with low red-cell folates: implications for folate intake recommendations. Lancet 349, 1591-1593.

Molloy, A.M., Mills, J.L., Kirke, P.N., Whitehead, A.S., Weir, D.G. \& Scott, J.M. (1998). Whole blood folate values in subjects with different methylenetetrahydrofolate reductase genotypes: differences between the radio assay and microbiological assay. Clinical Chemistry (in press). 
Molloy, A.M. \& Scott, J.M. (1998). Microbiological assay for serum, plasma, and red cell folate using cryopreserved, microtiter plate method. Methods in Enzymology 281, 43-53.

Morrison, H.I., Schaubel, D., Desmeules, M. \& Wigle, D.T. (1996). Serum folate and risk of fatal coronary heart disease. JAMA: Joumal of the American Medical Association 275, 1893-1896.

Mudd, S.H., Finkelstein, J.D., Irreverre, F. \& Laster, L. (1964). Homocystinuria: an enzymatic defect. Science 143, 1443-1445.

Mudd, S.H., Levy, H.L. \& Skovby, F. (1995). Disorders of transsulfuration. In The Metabolic and Molecular Basis of Inherited Disease, pp. 1279-1327 [C.R. Scriver, A.L. Baendet, W. Sly and D. Valle, editors]. New York: McGrawHill.

Naurath, J., Joosten, E., Riezler, R., Stabler, S.P., Allen, R.H. \& Lindenbaum, J. (1995). Effects of vitamin B 12 , folate and vitamin $B_{6}$ supplements in elderly people with normal serum vitamin concentrations. Lancet 346, 85-89.

Neaton, J.D. \& Wentworth, D. (1992). Serum cholesterol, blood pressure, cigarette smoking, and death from coronary heart disease: overall findings and differences by age for 316,099 white men. Archives of Internal Medicine 152, 56-64.

Neugebauer, S., Baba, T., Kurokawa, K. \& Watanabe, T. (1997). Defective homocysteine metabolism as a risk factor for diabetic retinopathy. Lancet $349,473-474$.

Nordstrom, M. \& Kjellstrom, T. (1992). Age dependency of cystathionine $\beta$-synthase activity in human fibroblasts in homocyst(e)inaemia and atherosclerotic vascular disease. Atherosclerosis 94, 213-221.

Nygard, O., Nordehaug, J.E., Refsum, H., Ueland, F.M., Farstad, M. \& Vollset, S.E. (1997). Plasma homocysteine levels and mortality in patients with coronary artery disease. New England Journal of Medicine 337, $230-236$.

Oakley, G.P. (1997a). Let's increase folic acid fortification and include vitamin $B_{12}$. American Joumal of Clinical Nutrition 65, 1889-1890.

Oakley, G.P. (1997b). Folic acid deficiency's role expands beyond birth defects. Scientist 11, $10-11$.

Ou, C.-Y., Stevenson, R.F., Brown, V.K., Schwartz, C.E., Allen, W.P., Khoury, M., Oakley, G.P. \& Adams, M.J. (1995). C677T homozygosity associated with thermolabile 5,10 methylenetetrahydrofolate reductase as a risk factor for neural tube defects. American Journal of Human Genetics 57, A223.

Pancharuniti, N., Lewis, C.A., Sauberlich, H.E., Perkins, L.L., Go, R.C.P., Alvarez, J.O., Macaluso, M., Acton, R.T., Copeland, R.B., Cousins, A.L., Gore, T.B., Cornwell, P.E. \& Roseman, J.M. (1994). Plasma homocyst(e)ine, folate, and vitamin B-12 concentrations and risk for early-onset coronary artery disease. American Journal of Clinical Nutrition 59, 940-948.

Papapetrou, C., Lynch, S.A., Bum, J. \& Edwards, Y.H. (1996). Methylenetetrahydrofolate reductase and neural tube defects. Lancet 348, 58.

Parfrey, P.S. (1993). Cardiac and cerebrovascular disease in chronic uraemia. American Journal of Kidney Diseases 21 , 77-80.

Perna, A.F., Ingrosso, D., Galletti, P., Zappia, V. \& De Santo, N.G. (1996). Membrane protein damage and methylation reactions in chronic renal failure. Kidney International 50, 358-366.

Perry, I.J., Refsum, H., Morris, R.W., Ebrahim, S.B., Ueland, P.M. \& Shaper, A.G. (1995). Prospective study of serum total homocysteine concentration and risk of stroke in middle-aged British men. Lancet 346, 1395-1398.

Peterson, J.C. \& Spena, J.D. (1998). Vitamins and progression of atherosclerosis in hyperhomocysteinaemia. Lancet $351,263$.

Petri, M., Roubenoff, R., Dallal, G.E., Nadeau, M.R., Selhub, J. \& Rosenberg. I.H. (1996). Plasma homocysteine as a risk factor for atherothrombotic events in systemic lupus erythematosus. Lancet 348, 1120-1124.

Rasmussen, K., Moller, J., Lyngbak, M., Pedersen, A.M.H. \& Dybkjaer, L. (1996). Age- and gender-specific reference intervals for total homocysteine and methylmalonic acid in plasma before and after vitamin supplementation. Clinical Chemistry 42, 630-636.

Refsum, H. Ueland, P.M. Nygard, O. \& Vollset, S.E. (1998). Homocysteine and cardiovascular disease. Annual Review of Medicine 49, 31-62.

Robillon, J.F., Canivet, B., Candito, M., Sadoul, J.L., Jullien, D., Morand, P., Chambon, P. \& Freychet, P. (1994). Type I diabetes mellitus and homocyst(e)ine. Diabète et Métabolisme 20, 494-496.

Robinson, K., Gupta, A., Dennis, V., Arheart, K., Chaudhary, D., Green, R., Vigo, P., Mayer, E.L., Selhub, J., Kutner, M. \& Jacobsen, D.W. (1997). Hyperhomocysteinaemia confers an independent increased risk of atherosclerosis in end-stage renal disease and is closely linked to plasma folate and pyridoxine concentrations. Circulation 94, 27432748.

Robinson, K., Mayer, E., Miller, D., Green, R., van Lente, F., Gupta, A., Kottke-Marchant, K., Savon, S.R., Selhub, J., Nissen, S.E. et al. (1995). Hyperhomocysteinemia and low pyridoxal phosphate: common and independent reversible risk factors for coronary artery disease. Circulation 92, 2825-2830.

Rodgers, G.M. \& Conn, M.T. (1990). Homocysteine, an atherogenic stimulus, reduces protein C activation by arterial and venous endothelial cells. Blood 75, 895-901.

Rosenblatt, D.S. (1995). Inherited disorders of folate transport. In The Metabolic and Molecular Basis of Inherited Disease, pp. 821-844 [C.R. Scriver, editor]. New York: McGraw-Hill.

Roubenoff, R., Delloripa, P., Nadeaa, M.R., Abad, L.W., Muldoon, B.A., Selhub, J. \& Rosenberg, I.H. (1997). Abnormal homocysteine metabolism in rheumatoid arthritis. Arthritis and Rheumatism 40, 718-722.

Scott, J.M. \& Weir, D.G. (1981). The methyl folate trap. Lancet ii, 337-340.

Scott, J.M. \& Weir, D.G. (1996). Homocysteine and cardiovascular disease. QJM: Monthly Journal of the Association of Physicians 89, 561-563. 
Scott, J.M., Dinn, J.J., Wilson, P. \& Weir, D.G. (1981). Pathogenesis of subacute combined degeneration: a result of methyl group deficiency. Lancet ii, 334-337.

Selhub, J., Jacques, P.F., Bostom, A.G., D’Agostino, R.B., Wilson, P.W.F., Belanger, A.J., O'Leary, D.H., Wolf, P.A., Schaefer, E.J. \& Rosenberg, I.H. (1995). Association between plasma homocysteine concentrations and extracranial carotid artery stenosis. New England Joumal of Medicine 332, 286-291.

Selhub, J., Jacques, P.F., Wilson, P.W.F., Rush, D. \& Rosenberg, I.H. (1993). Vitamin status and intake as primary determinants of homocysteinemia in an elderly population. JAMA: Journal of the American Medical Association 270. 2693-2698.

Skovby, F. (1985). Homocystinuria, clinical, biochemical and genetic aspects of cystathionine beta-synthase and its deficiency in man. Acta Paediatrica Scandinavica Suppl. 321, 1-21.

Skovby, F., Kraus, J.P. \& Rosenberg, L.E. (1984). Biosynthesis of human cystathionine $\beta$-synthase in cultured fibroblasts. Journal of Biological Chemistry 259, 583-587.

Stabler, S.P., Allen, R.H., Savage, D.G. \& Lindenbaum, J. (1990). Clinical spectrum and diagnosis of cobalamin deficiency. Blood 76, 871-881.

Stamler, J.S., Osborne, J.A., Jaraki, O., Rabbani, L.E., Mullins, M., Singel, D. \& Loscalzo, J. (1993). Adverse vascular effects of homocysteine are modulated by endothelium-derived relaxing factor and related oxides of nitrogen. Journal of Clinical Investigation 91, 308-318.

Stampfer, M.J., Malinow, M.R., Willett, W.C., Newcomer, L.M., Upson, B., Ullmann, D., Tishler, P.V. \& Hennekens, C.H. (1992). A prospective study of plasma homocyst(e)ine and risk of myocardial infarction in US physicians. JAMA: Joumal of the American Medical Association 268, 877-881.

Talbot, R.W., Heppell, J., Dozois, R.R. \& Beart, R.W. (1986). Vascular complications of inflammatory bowel disease. Mayo Clinic Proceedings 61, 140-145.

Tamura, T., Johnston, K.E. \& Bergman, S.M. (1996). Homocysteine and folate concentrations in blood from patients treated with hemodialysis. Joumal of the American Society of Nephrology 7, 2414-2418.

Tsai, J.-C., Perrella, M.A., Yoshizumi, M., Hsieh, C.M., Haber, E., Schlegel, R. \& Lee, M.E. (1994). Promotion of vascular smooth muscle cell growth by homocysteine: a link to atherosclerosis. Proceedings of National Academy of Sciences of the USA 91, 6369-6373.

Tsai, M.Y., Bignell, M., Schwichtenberg, K. \& Hanson, N.Q. (1996a). High prevalence of a mutation in the cystathionine $\beta$-synthase gene. American Journal of Human Genetics 59, 1262-1267.

Tsai, M.Y., Garg, U., Key, N.S., Hanson, N.Q., Suh, A. \& Schwichtenberg, K. (1996b). Molecular and biochemical approaches in the identification of heterozygotes for homocysteinuria. Atherosclerosis 122, 69-77.

Tucker, K.L., Mahnken, B., Wilson, P.W.F., Jacques, P. \& Selhub, J. (1996). Folic acid fortification of the food supply. Potential benefits and risks for the elderly population. JAMA: Joumal of the American Medical Association 276, 1879-1885.

Ueland, P.M. \& Refsum, H. (1989). Plasma homocysteine - a risk factor for vascular disease: plasma levels in health, disease and drug therapy. Journal of Laboratory and Clinical Medicine 114, 473-501.

Ueland, P.M., Refsum, H., Stabler, S.P., Malinow, M.R., Andersson, A. \& Allen, R.H. (1993). Total homocysteine in plasma or serum: methods and clinical application. Clinical Chemistry 39, 1764-1779.

van Bockxmeer, F.M., Mamotte, C.D.S., Vasikaran, S.D. \& Taylor, R.R. (1997). Methylenetetrahydrofolate reductase gene and coronary artery disease. Circulation 95, 21-23.

van der Mooren, M.J., Wouters, M.G.A.J., Blom, H.J., Schellekens, L.A., Eskes, T.K.A.B. \& Rolland, R. (1994). Hormone replacement therapy may reduce high serum homocysteine in post-menopausal women. European Journal of Clinical Investigation 24, 733-736.

van der Put, N.M.J., Eskes, T.K.A.B. \& Blom, H.J. (1997). Is the common C677C-T mutation in the methylenetetrahydrofolate reductase gene a risk factor for neural tube defects? A meta analysis. QJM: Monthly Joumal of the Association of Physicians 90, $111-115$.

van der Put, N.M.J., Steegers-Theunissen, R.P.M., Frosst, P., Trijbels, F.J.M., Eskes, T.K.A.B., van den Heuvel, L.P., Mariman, E.C.M., den Heyer, M., Rozen, R. \& Blom, H.J. (1995). Mutated methylenetetrahydrofolate reductase as a risk factor for spina bifida. Lancet 346, 1070-1071.

Vasikaran, B.D. \& van Bockxmeer, F.M. (1997). Mild to moderate hyperhomocysteinaemia; a risk factor for vascular disease. Clinical Biochemistry Reviews 18, 55-62.

Verhoef, P., Hennekens, C.H., Allen, R.H., Stabler, S.P., Willett, W.C. \& Stampfer, M.J. (1997). Plasma total homocysteine and risk of angina pectoris with subsequent coronary artery bypass surgery. American Joumal of Cardiology 79, 799-801.

Verhoef, P., Hennekens, C.H., Malinow, M.R., Koh, F.J., Willett, W.C. \& Stampfer, M.J. (1994). A prospective study of plasma homocyst(e)ine and risk of ischemic stroke. Stroke 25, 1924-1930.

Verhoef, P. \& Stampfer, M.J. (1995). Prospective studies of homocysteine and cardiovascular disease. Nutrition Reviews 33, 283-288.

Wald, N.J., Watt, H.C., Law, M.R., Weir, D.G., McPartlin, J. \& Scott, J.M. (1998). Homocysteine and ischaemic heart disease: results of a prospective study with implications on prevention. Archives of Internal Medicine 158, 862-867.

Wang. J., Dudman, N.P.B., Wilcken, D.E.L. \& Lynch, J.F. (1992). Homocysteine catabolism: levels of 3 enzymes in cultured human vascular endothelium and their relevance to vascular disease. Atherosclerosis 97, 97-106. 
Ward, M., McNulty, H., McPartlin, J., Strain, J.J., Weir, D.G. \& Scott, J.M. (1997). Plasma homocysteine, a risk factor for cardiovascular disease, is lowered by physiological doses of folic acid. QJM: Monthly Joumal of the Association of Physicians 90, 519-524.

Weir, D.G. \& Scott, J.M. (1995). The biochemical basis of the neuropathy in cobalamin deficiency. In Clinical Haematology: Megaloblastic Anaemia, vol. 8, pp. 479-497 [S.N. Wickramasinghe, editor]. London: Bailliere.

Whitehead, A.S., Gallagher, P., Mills, J.L., Kirke, P.N., Burke, H., Molloy, A.M., Weir, D.G., Shields, D.C. \& Scott, J.M. (1995). A genetic defect in 5,10-methylenetetrahydrofolate reductase in neural tube defects. QJM: Monthly Joumal of the Association of Physicians 88, 763-766.

Wilcken, D.E.L. (1997). MTHFR 677C $\rightarrow \mathrm{T}$ mutation, folate intake, neural-tube defect, and risk of cardiovascular disease. Lancet 350, 603-604.

Wilcken, D.E.L., Gupta, V.J. \& Reddy, S.G. (1980). Accumulation of sulfur-containing amino acids including cysteinehomocysteine in patients on maintenance hemodialysis. Clinical Science 58, 427-430.

Wilcken, D.E.L., Wang, X.L., Sim, A.S. \& McCredie, R.M. (1996). Distribution in healthy and coronary populations of the methylenetetrahydrofolate reductase (MTHFR) C677T mutation. Arteriosclerosis, Thrombosis and Vascular Biology 16, 878-882.

Wilcken, D.E.L. \& Wilcken, B. (1976). The pathogenesis of coronary artery disease: a possible role for methionine metabolism. Journal of Clinical Investigation 57, 1079-1082.

Wild, J., Schorah, C.J., Maude, K. \& Levene, M.I. (1996a). Folate intake in young women and their knowledge of preconceptional folate supplementation to prevent neural tube defects. European Journal of Obstetrics and Gynecology and Reproductive Biology 70, 185-189.

Wild, J., Schorah, C.J., Maude, K. \& Levene, M.I. (1996b). Girls should be taught at school about importance of folic acid. British Medical Joumal 312, 974.

Wouters, M.G.A.J., Moorrees, M.T.E.C., van der Mooren, M.J., Bloom, H.J., Boers, G.H.J., Schellekens, L.A., Thomas, C.M.G. \& Eskes, T.K.A.B. (1995). Plasma homocysteine and menopausal status. European Journal of Clinical Investigation 25, 801-805. 